\title{
Critical review on arsenic: Its occurrence, contamination and remediation from water and soil
}

\author{
K M Meghana \\ Department of Life Sciences, Christ University, Bengaluru - 560029 (Karnataka), India \\ D Sayantan* \\ Department of Life Sciences, Christ University, Bengaluru - 560029 (Karnataka), India \\ *Corresponding author. Email: sayantan.d@christuniversity.in
}

\section{Article Info}

https://doi.org/10.31018/

jans.v13i3.2757

Received: June 3, 2021

Revised: August 1, 2021

Accepted: August 5, 2021

\section{How to Cite}

Meghana, K M and Sayantan, S (2021). Critical review on arsenic: Its occurrence, contamination and remediation from water and soil. Journal of Applied and Natural Science, 13(3), 861 - 879. https://doi.org/10.31018/jans.v13i3.2757

\begin{abstract}
With the increasing pollution in today's world, importance is being given to solve a problem and do it in a sustainable, ecofriendly manner. Arsenic is a class- 1 carcinogen and also causes many other side effects to humans, plants and animals. The utilization of arsenic as wood preservatives, pesticides, or its historical overuse by some military units for rice killing operations has led to the increase in the toxic effects of arsenic like its carcinogenicity, decreased immune response etc. Although conventional methods like coagulation, lime softening, adsorption, membrane technology are effective, they have their disadvantages like additional waste generation, causing increased pollution and are expensive. The better alternative is phytoremediation. Appropriate plants like Brassica juncea, Hydrilla verticilata, Pteris vittata L., Vallisneria natans, can be chosen based on the method of the remediation like phytoextraction, phytostabilization and phytofiltration or phytovoltalization. This review provides the list of a few plants which can be likely chosen for the purpose of both water and soil remediation. Advancements are occurring in bioremediation studies with the development of transgenic plants like transgenic tobacco, transgenic Arabidopsis thaliana for better phytoremediation. Understanding the mechanism employed by the plant for its uptake/detoxification can aid in the enhancement of the process of remediation with the external supply of phosphorus. Along with this, the proper and safe disposal of plants is crucial for the remediation process. In addition, awareness of this solution to the general public is to be made for its effectiveness.
\end{abstract}

Keywords: Arsenate [As(V)], Arsenite [As (III)], Contamination, Phytoremediation, Toxicity

\section{INTRODUCTION}

Arsenic poisoning has been common in various countries like India, Argentina, Bangladesh, China, European countries, Nepal, the United States, Vietnam (Krämer, 2005; Shaji et al., 2021). In addition to its natural sources of occurrences, the excessive usage of arsenic as wood preservatives, pesticides, food additives led to the increased arsenic concentration in soil and underground water (Peryea and Creger, 1994; Hingston et al., 2001). Consumption/drinking of this arsenic polluted water is causing serious health effects to humans, plants and animals. The carcinogenicity of arsenic is also quite high and can cause cancer of the skin, bladder, kidney or lung even with minute exposure. In plants, necrosis, stunted growth, low yield, withered leaves and even death are observed with arsenic exposure (Mandal and Suzuki, 2002; Abbas et al., 2018; Palma-Lara et al., 2020). Therefore, this pressing problem has to be addressed efficiently. Conventional physical and chemical methods like coagulation, ion exchange, lime softening, adsorption, filtration etc., though are effective to an extent, can be expensive, involve high labour in handling, and create additional waste products during the process (Srivastava and dwivedi, 2015). An environmentally friendly process with little maintenance and costeffectiveness is the use of plants (phytoremediation) or bacteria (bioremediation) for the removal/stabilization/ conversion of arsenic into a less toxic form. With the advancements in genetic engineering, the usage of transgenic plants or bacteria for better and easy removal of arsenic is also in practice (Irshad et al., 2021). This review gives a detailed idea of the conventional methods in practice and their better alternatives, emphasising on the types of plants that aid in the phytoremediation of arsenic. The safe disposal of arsenic adsorbed plants has also been discussed here. 


\section{SOURCES AND OCCURRENCE OF ARSENIC}

Arsenic $(Z=33)$ is the $20^{\text {th }}$ most abundant element in the geosphere and it has an average abundance of about 5 $\mathrm{mg} / \mathrm{kg}$ in the earth's crust (Garelick et al., 2008). It is a colourless, odourless and tasteless poisonous element (Katsoyiannis and Zouboulis, 2006). It occurs naturally as ores, usually in combinations with sulphur like Realgar (AsS), Orpiment $\left(\mathrm{As}_{2} \mathrm{~S}_{3}\right)$, Arsenopyrite (FeAsS) (Magalhães, 2002). Weathering of these minerals or rocks would form the particulate arsenic (as Arsenic trioxide), which then dissolves with rainwater and enters the soil /groundwater. Elevated concentration of arsenic is seen in the groundwater in countries like Argentina, Bangladesh, Chile, China, India, Mexico and the United States of America (Melkonian et al., 2011). In the soil system, the $\mathrm{pH}$ governs the availability of arsenic (Signes-Pastor et al., 2007).

Volcanic eruptions, dust storms, forest fires are some of the natural causes of the availability of arsenic. The process of arsenic occurrence in the environment is enhanced due to anthropological usage like mining, metallurgy, processing of ores, burning of fossil fuels, industrialization, its use as a wood preservative etc. (Taylor et al., 2003; Raj, 2019). Apart from these, the use of pesticides and herbicides containing arsenic, inclusion as an additive in the feed of livestock has led to the drastic elevation of the arsenic concentration in the soil and water, causing several toxic effects to plants and animals (Smedley and Kinniburgh, 2002; Irshad et al., 2021).

Arsenic is found majorly in four oxidation states: arsenate $(+5)$, arsenite $(+3)$, arsenic $(0)$, and arsenide $(-3)$. Usually, arsenic in -3 and 0 oxidation states are found to be unstable in soil (Xie and Huang, 1998). The inorganic forms of arsenic are common in mineral forms and are highly toxic. The inorganic form when enters the food chain gets methylated and less toxic organic forms like MMA (Monomethyl arsine), DMA (Dimethyl arsine), TMA (Trimethyl arsine) are formed. Other organic forms of arsenic like arsenobetaine (which is possibly produced by zooplanktons or phytoplanktons) (Edmonds and Francesconi, 1988; Lee and Wen, 2019), arsenocholine (immediate precursor of arsenobetaine) (Landner, 1998; Chen et al., 2020) can be taken up by some fish, shellfish and can be buildup in its tissues. This is usually referred to as 'fish arsenic' and is less harmful (Chou and De Rosa, 2003). Arsenate is the chemical analogue of phosphate and is the thermodynamically stable form in aerobic conditions, while arsenite is dominant in anaerobic conditions like submerged soil conditions (Abedin et al., 2002; SignesPastor et al., 2007) and also in flooded water conditions. This is the reason for increased arsenite concentration in plants like rice which need flooded water conditions (Yamaguchi et al., 2011; Awasthi et al., 2017).

\section{HISTORICAL USE OF ARSENIC}

Arsenic was first isolated in $1250 \mathrm{CE}$. And ever since it has been used historically as a drug in the treatment of skin infections and for beautification (Shrivastava et al., 2015). It has also been utilized as a pesticide for grape plants, cotton and orchards in arsenate $\left(\mathrm{AsO}_{4}{ }^{3-}\right)$ form (Taylor et al., 2003). About $50 \%$ of arsenic is used in the production of pesticides, and $30 \%$ in the formulating of wood preservatives ( e.g. chromated copper arsenate- CCA) to make the wood resistant to decay (Garelick et al., 2008; Rahman and Hasegawa, 2011). CCA has been applied onto the timber that is specially used for marine conditions as it preserved it from being damaged by wood-boring crustaceans and molluscs and decay by soft rot fungi and lignolytic bacteria (Brown et al., 2001).

Arsenite has been used as rodenticide, herbicide, and insecticidal bait because of its high solubility and rapid toxicity. Johnson grass (Sorghum halepsense), grown primarily in cotton fields, can be controlled by the use of dimethylarsinic acid and disodium methyl arsenate. Cocadylyic acid, marketed with the name 'Agent Blue' used by military forces in the 1960s for 'rice-killing operations' of their enemies, is an organic arsenic compound with high solubility (Bencko and Foong, 2017). Arsenic was used as an additive to livestock feed until its ban at the end of the $20^{\text {th }}$ century (Jones, 2007). Roxarsone (3-nitro4-hydroxyphenyl arsonic acid) was used in chicken farming feed, as it aided in weight gain, control of infectious agents, enhanced feed utilization and improved meat pigmentation (Fisher et al., 2015). During $1900-1955$, arsenic was observed to be used to control ticks in cattle (Rahman et al., 2019). Other applications of arsenic usage are lead-acid batteries for automobiles, light-emitting diodes, and semiconductors (Chou and De Rosa, 2003).

Incidents related to the consumption of arseniccontaminated food were also recorded historically. The Manchester epidemic of 1900 due to consumption of arsenic-contaminated beer (Phillips and French, 1998) and the acute arsenic poisoning outbreak due to contaminated soya sauce in Japan during 1956 (Mizuta et al., 1956) are noteworthy episodes in history (Naidu et al., 2006).

\section{TOXIC EFFECTS OF ARSENIC ON BIOSPHERE}

World Health Organization (WHO) has set a limit with a concentration of arsenic below $10 \mu \mathrm{g} / \mathrm{L}$ as safe for drinking water (https://www.who.int/news-room/fact-she ets/detail/arsenic) while the national standard for drinking water in Bangladesh is $50 \mathrm{mgL}^{-1}$ (Islam et al., 2015). However, some studies show that even that leads to the mortality risk (D'lppoliti et al., 2015). Arsenic is a highly toxic metal and a class- 1 carcinogen affecting 
the liver, lung, skin, kidney and bladder (Raj and Singh, 2015). Substances that are categorized under class1 carcinogens can definitely cause cancer with enough supporting evidence (McGregor et al., 2010). In addition to causing cancer, inorganic arsenic is also seen to act as a potential endocrine disruptor, specifically influencing glucocorticoid receptor (GR)associated gene expression, although detailed mechanism is yet to be under stood (Meakin et al., 2019).

In the plant system, arsenic competes with phosphate and enters through phosphate channels, leading to phosphate imbalance, formation of unstable adducts and thereby leading to lesser production of ATP in the cell (Sayantan and Shardendu, 2017). As(V) also hinders the phosphate of nucleic acid, thereby the DNA synthesis, while As(III) binds to sulfhydryl groups of peptides and proteins and interferes with their activities (Mishra et al., 2017). Additional toxic effects of arsenic include oxidative stress, alterations in cell signalling and DNA repair (Kozul et al., 2009). Toxicity of arsenic is in the order: arsenite > arsenate > MMA > DMA (Carbonell-Barrachina et al., 2000).

\section{Plants}

Arsenic is a non-essential element and is toxic to plants as well (Garg and Singla, 2011). When arsenic enters the plants, they interfere with the various metabolic processes, induces oxidative stress due to the formation of reactive oxygen species (ROS) like superoxide radical $\left(\mathrm{O}^{2-}\right)$, hydroxyl radical $(\cdot \mathrm{OH})$, and hydrogen peroxide $\left(\mathrm{H}_{2} \mathrm{O}_{2}\right)$ during the conversion of $\mathrm{As}(\mathrm{V})$ to $\mathrm{As}$ (III) (Sharma, 2012). Diminishing in the tissue respiration and energy supply can also be seen in the plant due to impaired glycolysis and the TCA cycle. This is due to the replacement/ interaction of phosphate and sulfhydryl groups (-SH ) of enzymes /biomolecules with As (V) and As (III) respectively (Thakur et al., 2020).

Visible toxic effects observed in plants include inhibition of seed germination, discoloured-stunted roots, necrosis, chlorosis, decreased photosynthetic activity, withered leaves, reduced fruit and grain yield, and in extreme cases, even death. In most plants, the arsenic toxicity threshold limit in sandy and clay soils is 40 and $200 \mathrm{mg} \mathrm{kg}^{-1}$, respectively (Vithanage et al., 2012).

Literature supports the higher accumulation of arsenic in plants like paddy because of higher bioavailability in soil, which is due to the fact that they are to be cultivated in water bed conditions. Therefore, they (Oryza sativa) are seen to accumulate 10 times more arsenic than other cereal plants. Reduced amylolytic activity is seen in wheat in arsenic toxic conditions. Arsenic is seen to obstruct the pigment biosynthesis through inhibition of tetrapyrrole synthesis when it reaches the chloroplast (Mishra et al., 2017).

\section{Animals}

Animals also show certain toxic effects when exposed to arsenic like abdominal pain, weakness, nausea, diarrhoea and death. Mucosal epithelial necrosis and renal tube and gastrointestinal capillaries degeneration are seen. Exposure to a long time can induce depression, dehydration, frequent urination, imbalance in body temperature. Cutaneal arsenic exposure can cause drying up and deadening of the skin (Shrivastava et al., 2015).

It has also been reported that arsenic inhalation in rodents can lead to nasal flow discharge and irritation in the eye. Autopsy reports showed reddened edematous gastric and intestinal mucosa, yellowing of liver, and lung edema in arsenic exposed animals (Shrivastava et al., 2015). Partial fibriosis is noticed in cattle if arsenic in the feed concentration in higher than 250ppm leading to stiffness and unsymmetrical growth of hocks and limb joints. In goats, an increase in the heart rate and respiratory rate, congested mucosa with drooling of saliva, convulsion, polyuria and reduced weight is observed (Mandal, 2017).

\section{Humans}

Humans show many effects due to exposure to arsenic through water and food. Almost every food like rice, vegetables and even meat is seen to be contaminated with arsenic and with imports and exports of food, even people living in non-arsenic contaminated areas are getting exposed to arsenic (Upadhyay et al., 2019). Oral exposure of arsenic can show certain long term effects like melanosis (hyperpigmentation), the appearance of small corns or warts on the palms, soles, and torso; leukomelanosis (hypopigmentation), carotid atherosclerosis, and cardiovascular diseases (Chou and De Rosa, 2003). Inhalation of arsenic is seen to cause respiratory diseases, impaired lung functions (Slavkovich et al., 2013), peripheral nervous disorders and impaired cognitive abilities and motor functions. Exposure to arsenic is also observed to be associated with diabetes, hypertension (Lalita et al., 2012), development of arsenicosis, reproductive and developmental defects (Visoottiviseth et al., 2002). As defined by WHO, arsenicosis is a "chronic health condition arising from prolonged ingestion (not less than 6 months) of arsenic above a safe dose, usually manifested by characteristic skin lesions, with or without the involvement of internal organs" (Das and Sengupta, 2008).

Arsenic is observed to impede the metabolic pathways, alter the metabolites specially involved in the metabolism of aminoacid, pyruvate and Krebs cycle (Martin et al., 2015). They also act as endocrine and mitochondrial function disruptors (Howard, 2018; Sodhi et al., 2019). It also shows effects on hormonal regulation via retinoic acid, thyroid hormone and estrogen receptors. 
Arsenic exposure may even compromise the body's immune response (Kozul et al., 2009). The methylation of inorganic arsenic, which is an important process can be affected by factors like smoking tobacco. It is shown to decrease the methylation process and causes the deposition of inorganic arsenic in hair, bone and skin, and altering the DNA repair process (Melkonian et al., 2011).

\section{METHODS TO REMEDIATE ARSENIC CONTAMINATION}

The contaminated sites are hazardous and serve as a potential threat to all life forms. Therefore, it is necessary to remediate the contaminated sites. For this conventionally, the methods implemented may be to dig up the contaminated soil and transfer it to a landfill (Joseph et al., 2018), usually away from the human activity, or contain the area of contamination or leaching (use of strong chemicals to desorb/ leach metals from the soil) (David, 1995). Any of these conventional methods do not solve the issue but simply would carry the problem from one place to another. It would also create a risk of toxicity during handling, transportation and excavation in addition to the high-cost factor (Mary, 2011).

Therefore, proper methods are to be employed which can destroy or convert the contaminant to a less-toxic form. Many physico-chemical methods are employed for this process like precipitation, filtration, sedimentation, ion exchange, etc. Alternatively, biological methods like phytoextraction, phytostabilization, phytodegradation, rhizodegradation, phyto filtration etc. are also used.

\section{Physico-chemical methods}

Physico- chemical methods involve the separation or removal of arsenic from the contaminated soil or water samples with the help of certain physical methods like sieves, electrodes or through chemicals like alumina, alum or the combination of both. Most electro/chemical methods help take off or separate $\mathrm{As}(\mathrm{V})$ than As (III). Therefore, treatment with strong oxidizing agents like chlorine, ferric chloride, permanganate, ozone or hydrogen peroxide is recommended to convert As(III) into As (V) (Ortega ., 2017). The most commonly used methods are discussed below:

\section{Coagulation}

Coagulation is the process through which the dissolved arsenic can be converted into a solid or a semi-solid form with the addition of certain coagulants. The rough aggregation with the destabilized metal particles along with the coagulants is known as floc (Hashmi and
Pearce, 2011). The most commonly used coagulants for arsenic remediation are alum (aluminium sulphate) and ferric chloride. Both of these chemicals are equally effective for the removal of arsenic on a molar basis. When the low doses of these coagulants are added, it leads to the formation of flocs with the rough aggregation of the colloidal particles, while an amorphous metal hydroxide floc is formed with the high doses of coagulants into which the colloidal particles get entrapped (Hering et al., 1996). The $\mathrm{pH}$ range for coagulation with iron is seen to be 5-8, while with alum is 5-7 (Grill et al., 1987). Adsorption, occlusion, filtration or sedimentation methods can be used to remove the coagulated material. The disadvantage of this method is the use of chemicals that can add colour and/or odour to the sample. Also, large volumes of contaminated sludge are generated with this method which causes disposal related problems (Kochian, 2004).

To prevent this problem, electrocoagulation can be used where coagulation can be achieved with the help of electrodes. The amount of sludge generated gets reduced as no coagulants are added. Hence, electrocoagulation is observed to be effective than the chemical coagulation method in treating water bodies (Nidheesh and Singh, 2017). The steps involved in this method are: Formation of coagulants by electrolytic oxidation are i) Contaminants destabilization, suspension of particulate and breaking of emulsion and ii) Floc formation by aggregation of the destabilized particles (Ali et al., 2011). Iron and aluminium electrodes are most commonly used for this process. Titanium, copper and zinc electrodes can also be used. The major drawback of this method is passivation and severe corrosion of electrodes in field conditions (Nidheesh and Singh, 2017).

\section{Lime softening}

Lime softening, a method commonly used for removing the hardness of water can also be used to remove arsenic in dissolved form. The addition of $\mathrm{Ca}(\mathrm{OH})_{2}$ and $\mathrm{Na}_{2} \mathrm{CO}_{3}$ to water will increase its $\mathrm{pH}$ due to hydroxide ion release and precipitates substances other than magnesium and calcium. Arsenic also precipitates along with this and comes out in the calcifier with the lime sludge produced by the process (Kochian, 2004). The process is highly $\mathrm{pH}$-dependent with an optimum 10.5 - 11. About $95 \%$ of As can be removed from the contaminated water at this $\mathrm{pH}$, whereas only $30 \%$ can be removed at $\mathrm{pH} 8.5$ (Litynska et al., 2017). The use of $\mathrm{Cl}$ can increase the removal efficiency of arsenic. At the end of the process, treatment with acid is probably necessary to lower the $\mathrm{pH}$ to the optimum drinking levels (Choong et al., 2007). Litynska and Babakov (2019) asssed this method as a non-environmental friendly one with high need for chemicals, large quantities of 
Meghana, K M and Sayantan, S / J. Appl. \& Nat. Sci. 13(3), 861 - 879 (2021)

waste generation, and medium treatment efficiency.

\section{Adsorption}

Adsorption is a process through which the particles will bind to a surface and will be held together with chemical or physical forces (Hashmi and Pearce, 2011). Adsorption is a process through which the particles will bind to a surface and will be held together with chemical or physical forces (Hashmi and Pearce, 2011).

lon exchange works on adsorption where the charged particles in the solution are exchanged with the solid particles. Ions would be held electrostatically onto the surface of a solid phase which can be exchanged with the similarly charged ions in the solution. For arsenic removal, traditional ion exchangers like clay can be used. The use of hybrid resins like the one made with Iron (III) oxides and HFO particles which have high affinity to both $A s(v)$ and As(III), can be effective as described by Greenleaf et al. (2006). The new form of ion exchange material used nowadays is the ion- exchange fiber, which is seen to have high adsorption/ desorption rates with ease to fabricate (Chaudhary and Farrell, 2014). Polyacrylonitrile (PAH) fibers, polyethyelene coates polyproplylene fibers and cellulose fibers are being used recently for arsenic removal. Lee et al. (2017) used the affordable and reusable amine-doped acrylic ion-exchange fibers, which showed a maximum adsorption capacity of $205.3 \pm 3.6 \mathrm{mg} / \mathrm{g} \mathrm{As}(\mathrm{V})$. The major drawback of this type of separation process is the use of concentrated aggressive chemicals such as acid, salt or alkali as regenerants which causes difficulties in disposing of this waste (Hashmi and Pearce, 2011).

Chemical Adsorption occurs when arsenic is adsorbed onto a chemical surface. The most commonly used adsorbent is the activated alumina $\left(\mathrm{Al}_{2} \mathrm{O}_{3}\right)$. The arsenic ions in the solution can be removed by adsorbing onto the active sites of an oxide $\left(\mathrm{Al}_{2} \mathrm{O}_{3}\right)$. The optimum $\mathrm{pH}$ for this process is observed to be between 5 and 5.6 (Katsoyiannis Zouboulis, 2006). Once the adsorption process is completed, the alumina is subjected to a caustic bath, which aids in the removal of the arsenic adsorbed layer. Then the alumina is to be rinsed with sulfuric acid for neutralization to occur. A prime disadvantage of this method is the loss of adsorptive capacity of alumina of about $5-10 \%$ for each run. As a result, it has to be replaced typically after every three to four generations (Kochian, 2004). The disposal of the sludge generated can be done by the cementitious solidification method, i.e., by either combining the sludge with the concrete in a controlled ratio or with clay for the process of brick manufacturing (Mandal et al., 2016). Nanotechnology also has applications in this process as they are non-toxic and with better sorption capacity (Song et al., 2020). For arsenic removal, organic nanoparticles, silicon-based nanomaterials, car- bonaceous nanomaterials are in use. Sadeghi et al. (2020) synthesised graphene oxide nano ribbon (GONR), by unzipping of multiwalled carbon nanotubes. GONR are seen to be efficient in this ultrasonic assisted adsorption of arsenic.

\section{Membrane technology}

This technology typically includes methods that use membranes as filters to remove the pollutant (arsenic) from the sample. Reverse osmosis and dialysis can be included in this process. The success of filtration will depend on choosing the proper membrane with the appropriate pore size. The particulate arsenate larger than the given pore size will be rejected/ retained because of the size exclusion. Improvements with this method can be made by choosing membranes with certain physicochemical properties like hydrophobicity or charge, leading to adsorption or repulsion (Katsoyiannis and Zouboulis, 2006).

Nano filtration and hyperfiltration are the two processes of reverse osmosis. Nanofiltration operates at relatively low-pressure reverse osmosis. It is primarily used to exclude larger dissolved solids. Because of its ability to remove the divalent ions like calcium and magnesium that causes hardness in water, this method can also be called membrane softening. Hyperfiltration, however, operates at higher pressures with a greater rejection of dissolved solids (Kartinen and Martin, 1995). The optimum $\mathrm{pH}$ for reverse osmosis is between 7.0 and 9.0 (Katsoyiannis and Zouboulis, 2006). Of the different membranes used, chitosan, zeolite membranes like Feexchanged natural zeolite, Alumina-modified zeolite and synthetic zeolite etc (Khatamian et al., 2017; Li et al., 2018c). A cross-flow filtration experiment performed with a combination of zeolite modified chitosan membrane is seen to show a higher rejection rate for As(III) (Mukhopadhyay et al., 2018). Cellulose acetate-zinc oxide combined matrix membrane prepared by Durthi et al. (2018) is shown to exhibit the capability to remove arsenic with high efficiency and flex rates when compared with that of the cellulose acetate membranes without the nanoparticles.

Electrodialysis is the process by which the separation of particles occurs through the membrane with the application of electric current (Ali et al., 2011). The potential difference applied will aid in the transfer of ions through the alternating anionic and cationic membranes, which are aligned in between positive and negative electrodes. This results in two flow systems- one with concentrated ions and the other diluted stream. The efficiency of the arsenic removal is seen to be dependent on the applied voltage and the initial concentration (Pham et al., 2021). No addition of chemicals is required and this method can also tolerate feed waters with high chlorides and sulfates. Highly cleanable, easily recoverable and durable membranes are being uti- 
lized for this process, which is an added advantage (Taylor et al., 2014). The major disadvantage of the filtration process is creating larger volumes of sludge, causing the problem with disposal.

Other physicochemical processes of separation of arsenic include distillation- where the water is made to evaporate with thermal energy and then made to condense onto the roof of the cooler surface. Impurities like arsenic will be left behind and thus can be separated (Hashmi and Pearce, 2011).

Although these physicochemical methods for remediation come with drawbacks like generation of larger volumes of sludge, expensive to implement, nonenvironmental friendly, complex procedures, labour intensive can lead to the destruction of soil texture and characteristics (Abdulsalam et al., 2011). Therefore a cheaper, sustainable and ecofriendly/green alternative methods are to be considered (Abdulsalam et al., 2011). Biological remediation is an option in which the degradation or conversion of harmful contaminants occurs by employing plants or microorganisms. Thus, the remediation process occurs through a natural biological phenomenon, causing no damage to the soil texture/properties (Joseph et al., 2018). In fact, employing plants/soil microorganisms would enhance the quality of the soil in addition to remediation of arsenic and usually do not involve high expenditure.

\section{Phytoremediation}

As discussed earlier, biological remediation is a means to remediate the soil using plant and microbes. It is divided into phytoremediation and microbial remediation. Remediation of soil or water sample with the help of plants is called phytoremediation and remediation with microbes is microbial remediation (Tripti et al., 2017). A combination of these can also be used for the efficient removal of contaminants. Phytoremediation includes phytoextraction, phytostabilization, phytodegradation and phytofiltration.

\section{Phytoextraction}

Phytoextraction, also known as phytoaccumulation, or phytosequestration is the easiest and desirable way of removing a contaminant from the soil or water medium. It involves the extraction of contaminants from the soil or water with the help of terrestrial/ aquatic plants. The contaminant would be taken up by the roots and translocated to the leaves, which can then be harvested (Nedjimi, 2021). Thus, a fraction of the contaminant can be removed from the soil.

The plants that are chosen for this method are known as 'Hyperaccumulator' plants. Plants that can accumulate more than $0.1 \% \mathrm{DW}$ of a contaminant are called hyperaccumulators (Nedjimi, 2021). The ideal characteristics of these plants involve greater above-ground biomass, higher growth rate, efficient translocation, and easy to cultivate and harvest. Hyperaccumulators, which can accumulate metals naturally in their tissues without developing any toxic conditions and plants with highly branched root system would be ideal for the better uptake of contaminants (Bhargava et al., 2012). Hyperaccumulator plants that have the shoot to root metal concentration ratio greater than one are chosen for this method. Arsenic is usually localised in epidermal cells, mesophyll cells, and xylem tissues (Vithanage et al., 2012). Plants generally tend to store metals in the roots and prevent their transfer to the shoots as they can affect the photosynthesis, flowering capacity, etc., which is not observed in hyperaccumulators and thus as ideal for phytoextraction. Examples of hyper accumulator plants include Hydrilla verticilata, Vallisneria neotropicals (Chen et al., 2015; Li et al., 2018a), Pteris vittata L., (Poynton et al., 2004; Xie et al., 2009) Pityrogramma calomelons (Francesconi et al., 2002; Luongo and Ma, 2005). Hyperaccumulators might not always have high biomass, yet they would have a very high accumulation rate of target metal. Non -hyper accumulating plants with high biomass can also be employed, even though they do not have high specificity to the target metal as they can give a promising result overall, like Brassica juncea (Niazi et al., 2017). Once the contaminants get depleted from the soil to a certain extent, the plants are harvested. The harvested plants can either be smelted for potential metal recovery/ recycling or are to be disposed of safely as hazardous waste.

The translocation efficiency of the plant can be assessed with the calculation of certain factors like translocation factor (TF), enrichment coefficient of the shoot (ECS), bioaccumulation factor (BF). The phytoremediation efficiency of the plant is calculated based on the amount of arsenic translocated from the roots to shoots (Rahman and Hasegawa, 2011).

\section{Translocation factor (TF)}

An important aspect of characterising plant capacity in phytoremediation techniques is calculating TF. TF determines the ability of the plant to translocate a heavy metal from root to shoot parts. It is the ratio of the concentration of an element in the shoot $\left(\mathrm{mg} \mathrm{g}^{-1}\right)$ to the concentration of the same element in the root $\left(\mathrm{mg} \mathrm{g}^{-1}\right)$. Hyperaccumulators show high TF value, while the nonhyper accumulators usually have a value of less than one (Francesconi et al., 2002).

$$
T F=\frac{\text { conc.of element in shoot }}{\text { conc.of element in root }}
$$

\section{Enrichment coefficient of shoot (ECS)}

The ECS is another factor that can be used to assess the heavy metal uptake capacity of the plant. It is the ratio of the concentration of metal in the shoot to that of 
its concentration in the soil. When the ECS of a plant is greater than 1.0, it represents the typical capacity of that plant to transfer the metal to the shoot, mostly to the vacuoles (Elshamy et al., 2019).

$$
\text { ECS }=\frac{\text { Conc.of metal in shoot }}{\text { conc. of metal in soil }}
$$

\section{Bioaccumulation factor (BF)}

The bioaccumulation factor (BF) is used to evaluate the capability of the roots to take up the metals from the soil. BF is the concentration of an element collected in root tissues $\left(\mathrm{mg} \mathrm{g}^{-1}\right) /$ concentration of the same element in soil $\left(\mathrm{mg} \mathrm{g}^{-1}\right)$.

$$
B F=\frac{\text { conc.of metal in root tissue }}{\text { conc. of metal in soil }}
$$

Plants like Trifolium spp. with multiple harvest in a single growth period can be used. Grasses like barnyard grass (Sultana and Kobayashi, 2011), rice cutgrass (Klaber and Barker, 2014) are preferred to shrubs/ trees as they have high above ground biomass, growth rate and are more adaptable to stress (Ali et al., 2013). Care should be taken to prevent herbivores from consuming these plants leading to the contaminant entry into the food chain.

\section{Phytostabilization}

Phytostabilization or phytoimmobilization or in-place activation is a very efficient managing strategy in mining areas. This method stabilizes the contaminants, and thereby reduces their bioavailability and mobility. Thus, phytostabilization aids in reducing off-site contamination (Shrivastava et al., 2015). Plants secrete certain redox enzymes such as arsenate reductase and stabilize the contaminant (arsenic) through sorption, complexation/ metal valence reduction or precipitation it to less toxic forms (Thakur et al., 2020) and stabilize the contaminant (arsenic) through sorption, complexation/ metal valence reduction or precipitation and therefore convert it to less toxic forms. Thus, this method does not lead to the formation of any secondary waste, but it enhances soil fertility.

Plants suitable for phytostabilization should develop an extensive root system, provide good soil cover, possess tolerance to the contaminant metals, and ideally immobilize the contaminant in the rhizosphere, reducing leaching or bioavailability of arsenic and wind erosion (Silva Gonzaga et al., 2006). Ideally, plants chosen for Phytostabilization should have low pollutant accumulation in the shoots. If the plants chosen to accumulate the contaminant into the leaves/ tissues, contaminants can enter food chain; hence mostly the nonedible plants like Eucalyptus, Arundo donax L. can be chosen (Bolan et al., 2011; Mirza et al., 2011). When introduced with similar arsenic load, Woody plants like
Eucalyptus species gather arsenic at much lower levels than grasses, ferns, or other plants. Although this makes them less than ideal for phytoextraction, they are still a good choice for phytostabilization. Also, the leaves of these plants are rarely consumed by mammals because of certain defense compounds like terpenes, phenolics and cyanogenic glycosides, preventing their entry into the food chain (King et al., 2008).

However, it is to be noted that in the process of phytostabilization, only the movement of the metal is restricted and is not a permanent solution to the problem (Ali et al., 2013). The site is to be monitored at regular intervals to ensure that the optimal conditions are maintained. However, it is to be noted that in the process of phytostabilization, only the movement of the metal is restricted and is not a permanent solution to the problem (Ali et al., 2013). The site is to be monitored at regular intervals to ensure that the optimal conditions are maintained.

\section{Phytofiltration}

In general, Phytofiltration can be used to filter underground water, stormwater, subsurface water, wastewater etc. with a low concentration of contaminants and other effluents using aquatic macrophages or macroalgae (Garg and Singla, 2011; Shrivastava et al., 2015). In this method, the metal contaminants are adsorbed/absorbed onto the plant's surface, leading to lessening the concentration of pollutants in the water, i.e., filtering metals from water into the root system (Mykolenko et al., 2013). Therefore, the plants with high absorption surface area and those able to tolerate hypoxia are to be chosen. For example, Micranthemum umbrosum is seen as a strong accumulator of arsenic with the accumulation of about $1000 \mathrm{mg} \mathrm{As} \mathrm{g}^{-1}$ in its stem and leaf biomasses, potentially reducing the arsenic concentration in the solution of about 10-fold (Islam et al., 2015). In phytofiltration, the expulsion of arsenic from streaming water must be quick and so relies upon the water stream rate (Sandhi et al., 2018).

Phyto filtration can be of three types based on the part of the plant used for this purpose- rhizofiltration (roots), blastofiltration (seedling) and caulofiltration (excised shoots) (Ali et al., 2013). For Rhizofiltration to be effective, non-efficient metal transporters (as metal transport to the shoot makes rhizofiltration less efficient) and plants with extensive root system (e.g. Eucalyptus globulus, Acacia tortilis, Faidherbia albida) (Anawar et al., 2008) are to be chosen. Although to treat surface contaminated water, plants with shallow roots like grasses, Indian mustard or ferns can be used. At the end of the process, the roots can be harvested and dried. Depending on the purpose, the metals can be extracted by acid treatment or can be burned at hazardous waste sites (Dushenkov et al., 1995). Thus, phytofiltration 
becomes a very effective eco-friendly method to reduce contamination in the natural wetlands and estuary areas. Even arsenic-contaminated run off water from mines can be remediated by using Lemna gibba, which has high arsenic accumulation capacity (Anawar et al., 2008).

\section{Phytovoltalization}

The process involves the taking up of the contaminant from the soil and its release into the environment in the gaseous state in modified/ unmodified form at low concentrations through transpiration (Ranjan et al., 2020). The toxic pollutant is observed to be diluted in the atmosphere or is likely converted into a less toxic form. (Guarino et al., 2020). It can be divided into two types: direct and indirect. Direct involves the voltalization from the stem or roots or the leaves, while indirect involves the voltalization from the subsurface due to root activities (Pandey et al., 2018). It is the most controversial form of phytoremediation techniques. It involves the transfer of contaminant from one medium to the other, which could be redeposited back to the original medium. Thus, there seems to be little or no control over the movement of the contaminants (Bolan et al., 2011).

In contrast, certain studies show that the contaminants might not cause any harm to the environment. An additional advantage of this method is that no labor or effort is needed to transfer or dispose of the contaminated plant materials physically, thus requiring less management force (Heaton et al., 1998). It is seen that the presence of sulphate and salinity in the soil can hinder the process of volatilization (Vithanage et al., 2012).

Usually, arsenic is phytovoltalized in the form of trimethylarsine [TMAs(III)], the final product of methylation pathway in which As(III) is methylated to dimethylarsinic acid $[D M A(V)]$ and then to trimethylarsine oxide (TMAO) which is finally reduced to the volatile trimethylarsine [TMA(III)] (Mirza et al., 2011). P. vittata, the well-known hyperaccumulator of arsenic, can also be used in phytovolatilization. It is seen to release arsenic compounds into the environment through its secretory glands at the edges of the fronds (Sakakibara et al., 2007).

\section{PHYTOREMEDIATION OF ARSENIC CONTAMI- NATED WATER BODIES}

Contamination of water bodies is a serious threat to the living systems and it is to be addressed properly. Fig.1 and 2 show the arsenic contaminated water in different districts of India (Reddy, 2019). Among other chemical and physical methods, the natural bioremediation/ phytoremediation is a cost-effective and efficient method. The utilization of rapidly growing plants, like Eichhornia crassipes (water hyacinth), whose overpopulation is usually not desired, can be used to our advantage in decontaminating / remediating the polluted bodies (Ajayi and Ogunbayio, 2012). The metal removal rate of water hyacinth was reported to be $600 \mathrm{mg} \mathrm{As} / \mathrm{ha}$ by (Alvarado et al., 2008). In addition to water hyacinth, those showing hyper tolerance to As and capable of hyperaccumulating arsenic are also the key players in the game of phytoremediation. Over the years, these plants are identified, like Rorippa nasturtiumaquaticum L., Mentha spp. (Robinson et al., 2006), the Pteris ferns, Hydrilla verticillata (Xue Yan, 2011), Lepidium sativum (Robinson et al., 2003), Spirodela polyrhiza L., (M. A. Rahman et al., 2007) Eleocharis acicularis (Ha et al., 2011), Arundo donax L. with a high growth rate, the Macrophyte Lemna valdiviana is observed to reduce the arsenic concentration in water to about $82 \%$ of initial concentration under controlled factors like $\mathrm{pH}$, nitrate, phosphate concentrations (de Souza et al., 2019). In water bodies where the arsenic concentration is less than $30 \mathrm{ppm}$, the naturally grown Neptunia oleracea (Water mimosa) that has Rhizofiltration can be employed (Atabaki et al., 2020). Identifying plants with higher biomass having greater metal uptake capacity and employing them for the process of remediation is a sustainable and eco-friendly method to address this serious problem. Destruction of these plants from the water surface is to be avoided as they help in the control of heavy metal pollution and prevent their entry into the food chain (Sasmaz and Obek, 2009).

Another process employed for the phytoremediation of polluted water bodies is through constructed wetlands. Interactions between plants, soils, sediments and microbial communities always exist in a wetland and hence they are considered to be complex bioreactors (Corroto et al., 2019). The concept of constructed wetlands has been put into practice ever since the mid 1980's. Precipitation, coprecipitation and sorption are the major arsenic expulsion mechanisms incorporated in this system (Lizama et al., 2011). It is important to select metal tolerant plants, immobilize the contaminant in roots, and prevent the movement of these metals to the aerial parts of the plant, environmentally sustainable and easily implemented (Corroto et al., 2019). Table 1 represents various aquatic plants that are involved in the remediation of water bodies.

\section{PHYTOREMEDIATION OF ARSENIC CONTAMI- NATED SOIL}

Soil health, defined by the Natural Resources Conservation Service (NRCS, USA) as "the continued capacity of soil to function as a vital living ecosystem that sustains plants, animals and humans" (SanchezHernandez et al., 2019). Of the other factors affecting soil health like soil erosion, organic matter decline, biodiversity loss, contamination, loss of salinity etc., 
Meghana, K M and Sayantan, S / J. Appl. \& Nat. Sci. 13(3), 861 - 879 (2021)

Table 1: List of aquatic plants involved in phytoremediation of arsenic.

\begin{tabular}{|c|c|c|}
\hline PLANTS & CHARACTERISTICS & SOURCE \\
\hline Hydrilla verticilata & $\begin{array}{l}\text { It is a submerged macrophyte which acts as a bio- } \\
\text { indicator of arsenic pollution. It is also a phytofiltra- } \\
\text { tor, hyperaccumulator with fast growth and high } \\
\text { biomass. }\end{array}$ & $\begin{array}{l}\text { (Chen et al., 2015) } \\
\text { (Favas et al., 2012) } \\
\text { (Xue and Yan, 2011) }\end{array}$ \\
\hline Vallisneria natans & $\begin{array}{l}\text { It is a submerged rooted macrophyte, hyperaccu- } \\
\text { mulator, phytofiltrator with greater survival and } \\
\text { growth potential }\end{array}$ & $\begin{array}{l}\text { (Chen et al., 2015) } \\
\text { (Li et al., 2018a) }\end{array}$ \\
\hline Eichhornia crassipes & $\begin{array}{l}\text { It is a free- floating perennial extensively used to } \\
\text { phytoremediation with rapid multiplication and } \\
\text { greater biomass production. It can survive in wide } \\
\text { range of temperatures between } 1-40^{\circ} \mathrm{C}\end{array}$ & $\begin{array}{l}\text { (Jasrotia et al., 2014) } \\
\text { (Rahman and Hasegawa, 2011) } \\
\text { (Misbahuddin and Fariduddin, 2010) } \\
\text { (Newete and Byrne, 2016) }\end{array}$ \\
\hline Spirodela polyrhiza & $\begin{array}{l}\text { It is a free-floating macrophyte and is an efficient } \\
\text { phytofiltrator in contaminated water bodies and } \\
\text { paddy soils. It has high multiplication rates, short } \\
\text { life spans and easy to grow in various habitats. }\end{array}$ & $\begin{array}{l}\text { (Jasrotia et al., 2014) } \\
\text { (Favas et al., 2012) } \\
\text { (Rahman and Hasegawa, 2011) } \\
\text { (Islam et al., 2015) } \\
\text { (Zhang et al., 2011) }\end{array}$ \\
\hline $\begin{array}{l}\text { Micranthemum } \\
\text { umbrosum }\end{array}$ & $\begin{array}{l}\text { It is a rooted vascular plant, a strong accumulator } \\
\text { and an efficient phytofiltrator of arsenic without } \\
\text { showing any phytotoxic effect. }\end{array}$ & $\begin{array}{l}\text { (Jasrotia et al., 2014) } \\
\text { (Islam et al., 2015) } \\
\text { (Islam et al., 2017) }\end{array}$ \\
\hline Azolla caroliniana & $\begin{array}{l}\text { It is an annual floating fern and is a very good arse- } \\
\text { nic indicator. }\end{array}$ & $\begin{array}{l}\text { (Jasrotia et al., 2014) } \\
\text { (Favas et al., 2012) } \\
\text { (Islam et al., 2015) }\end{array}$ \\
\hline Ulothrix cylindricum & $\begin{array}{l}\text { It is a green algae and has been used as a cost } \\
\text { effective method of biosorption of As(III) from solu- } \\
\text { tions }\end{array}$ & (Jasrotia et al., 2014) \\
\hline Cladophora sp. & $\begin{array}{l}\text { It is a filamentous algae. It can be used to remedi- } \\
\text { ate arsenic- bearing waste water and make it suita- } \\
\text { ble for irrigation }\end{array}$ & (Jasrotia et al., 2014) \\
\hline Lemna gibba $L$. & $\begin{array}{l}\text { It is a free-floating aquatic angiosperm and an effi- } \\
\text { cient accumulator of arsenic }\end{array}$ & $\begin{array}{l}\text { (Sasmaz and Obek, 2009) } \\
\text { (Favas et al., 2012) }\end{array}$ \\
\hline $\begin{array}{l}\text { Ceratophyllum } \\
\text { demersum }\end{array}$ & $\begin{array}{l}\text { It is a rootless submerged aquatic plant shown to } \\
\text { accumulate arsenic with a } 20000 \text {-fold concentration } \\
\text { factor }\end{array}$ & (Favas et al., 2012) \\
\hline $\begin{array}{l}\text { Myriophyllum } \\
\text { propinquum }\end{array}$ & $\begin{array}{l}\text { It is a submerged macrophyte with high arsenic } \\
\text { accumulation potential }\end{array}$ & $\begin{array}{l}\text { (Favas et al., 2012) } \\
\text { (Rahman and Hasegawa, 2011) }\end{array}$ \\
\hline Lepidium sativum & $\begin{array}{l}\text { It is fast- growing shrub. It has high arsenic uptake } \\
\text { ability even from water containing relatively low } \\
\text { concentration of this element }\end{array}$ & $\begin{array}{l}\text { (Favas et al., 2012) } \\
\text { (Rahman and Hasegawa, 2011) }\end{array}$ \\
\hline Wolffia globose & $\begin{array}{l}\text { It is a root less duckweed with higher uptake effi- } \\
\text { ciency and tolerance competence }\end{array}$ & $\begin{array}{l}\text { (Rahman and Hasegawa, 2011) } \\
\text { (Islam et al., 2015) }\end{array}$ \\
\hline
\end{tabular}

heavy metal pollution is also a very serious threat and is to be addressed in an eco-friendly manner.

Growth and establishment of hyperaccumulating fern species like Pteris vittata can take up arsenic upto 4100 $\mathrm{mg} \mathrm{Kg}{ }^{-1}$ (Fayiga et al., 2004), Pityrogramma calo-

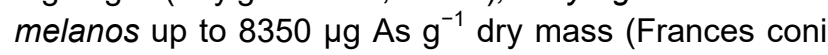
et al., 2002) in arsenic-contaminated area has shown to give promising results. Pteris vittata can accumulate about 10 times the concentration of arsenic in the soil when grown in arsenic-contaminated sites (Raj Singh, 2015). Harvesting these mature fronds on a regular basis will aid in the maximum removal of arsenic from the site of contamination. Brassica species like Brassica juncea, B. carinata and Isatis capadocica with the ability to produce high aboveground biomass and accu- mulate high arsenic concentrations in their shoots also aid in extracting high quantities of the heavy metals from soil (Karimi et al., 2003). Apart from these, even Mimosa pudica, a herb and Melastoma malabrathricum, a shrub, are also shown to phytoremediate the arsenic-contaminated soils (Rahman et al., 2007). Hyperaccumulator plants are generally used for phytoextraction. However, non-hyperaccumulating plants can also be manipulated to enhance their arsenic uptake efficiency by providing certain factors or conditions, e.g. the use of nonAs-hyperaccumulating Brassica sp. like Brassica juncea, Brassica napus with the assistance of phosphate, the chemical analogue of As(V) (Niazi et al., 2017). Table 2 represents various terrestrial plants that are involved in the remediation of soil. 


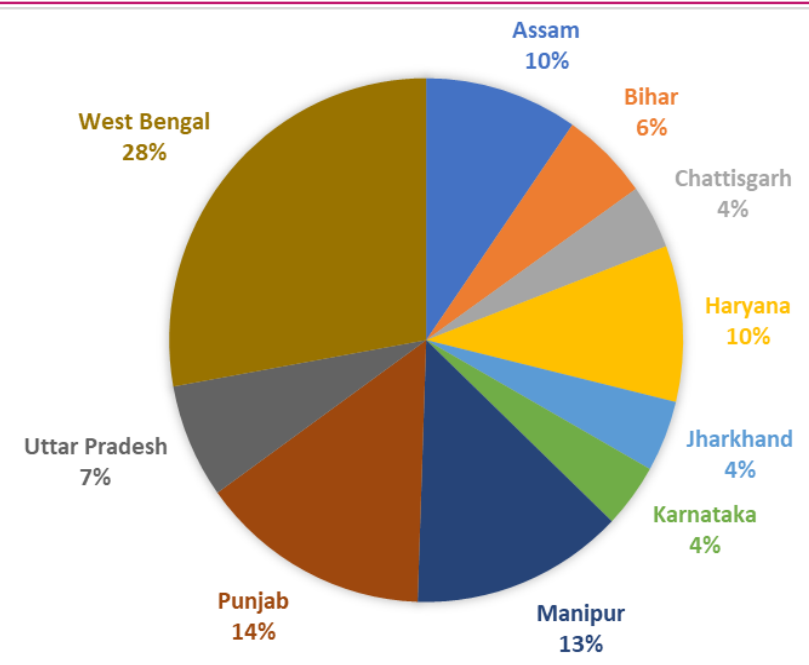

Fig. 1. Percentage of districts having arsenic $(>0.05 \mathrm{mg} / \mathrm{L})$ in ground water in different states of India.

GENETIC ENGINEERING FOR PHYTOREMEDIATION

Genetic engineering can also aid in phytoremediation by creating transgenic plants that have the ability to phytoremediate the metal. Higher tolerance is seen in the plants with higher AR activity. AR possesses the CDC25 - tyrosine phosphatase activity with a conserved HCX5R motif. The genes encoding AR are found in Arabidopsis (AtAsr / At ACR2), Holcus (HIAsr) and Pteris (PuACR2) (Tripathi et al., 2007). Transgenic tobacco is a genetically modified plant that had the AtACR2 gene of Arabidopsis thaliana expressed in them, and this plant was seen to survive in concentrations up to $200 \mu \mathrm{M}$ As, where the wild type cannot survive. Also, the arsenic accumulation in the aboveground biomass (edible part) was seen to be much low- er than wild, preventing arsenic entry into the food chain even when grown in contaminated lands (Nahar et al., 2017).

Another strategy for enhancing metal remediation was by elevating the synthesis of chelators like GSH and PCs, as the overexpression of phytochelatin synthase (PCS) showed encouraging outcomes in plants and bacteria. ATP-binding cassette class-C (ABCC) transporters, involved in ATP- powered translocation of many substrates across the membranes are also involved in the active transport of PC-conjugated As(III) into vacuoles. The over-expression of these transporters of Saccharomyces cerevisiae origin enhanced arsenic tolerance and accumulation in Arabidopsis thaliana (Song et al., 2010). The PCS enzyme is seen to be active only during the stressed conditions; otherwise, they remain inactive (Grill et al., 1987; Vatamaniuk et al., 2000).

In certain edible plant cases, the alternate mechanism of preventing the accumulation of arsenic in the plant is also in practice. The potential of biochar-DOM (Dissolved organic matter) interactions is found to be crucial for the suppression of movement and bioaccumulation of arsenic which is brought about by amending the agricultural paddy soils with biochar ( $\mathrm{Li}$ et al., 2018b).

\section{FATE OF ARSENIC IN PLANTS}

\section{Uptake of arsenic from soil to plants}

The process of transpiration serves as a driving force to absorb nutrients and other soil substances into the plant root and further to the shoots (Taylor et al., 2003). As (V) and $P$ are chemical analogues and therefore As (V) enters the plant through the inorganic phosphate

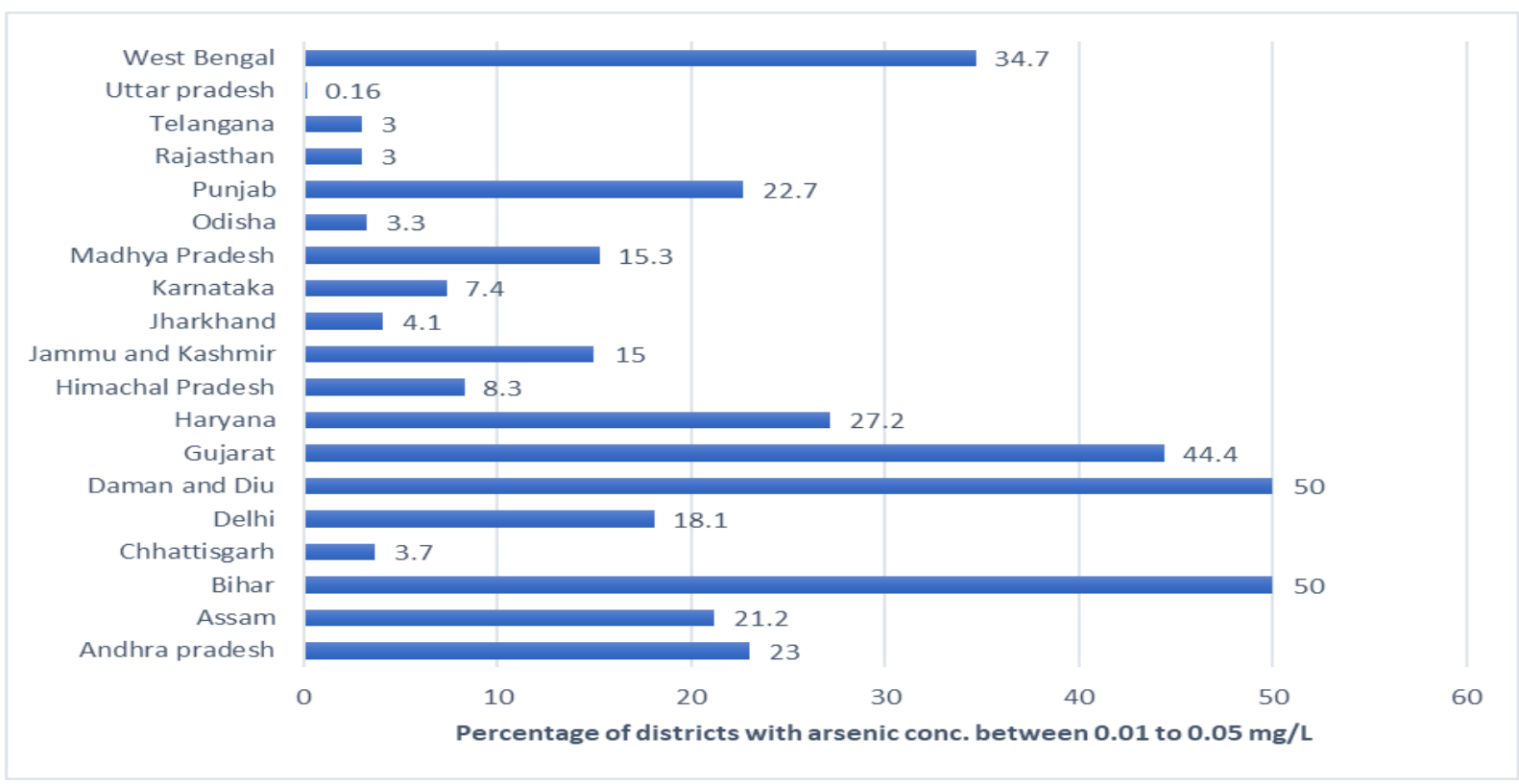

Fig. 2. Percentage of districts having arsenic (between 0.01 to $0.05 \mathrm{mg} / \mathrm{L}$ ) in ground water in different states of India. 
$(\mathrm{Pi})$ channels. The enhanced uptake of arsenate is observed in the plants when there is a presence of $\mathrm{As}(\mathrm{V})$ in the growth medium or a deficiency of phosphorus (Sayantan and Shardendu, 2017). Most of the arsenic uptake is through the phosphate transport system, (active uptake). A suppression in this system would reduce the arsenic influx. This strategy is employed by the arsenic- tolerant plants like Holcus lanatus and Cytisus striatus (Tripathi et al., 2007).

Although most of the arsenic is taken up by the plant in As (V) state, arsenic also enters the plants as As(III) in its neutral $\mathrm{As}(\mathrm{OH})_{3}$ form through aquaglyceroporins (passive uptake) (Tripathi et al., 2007). Methylarsenicals (DMAA and MMAA) are observed to enter the plant through this same pathway (Rahman, 2011). Nodulin 26- like intrinsic (NIPs) aquaporin channels mediate $\mathrm{As}$ (III) uptake along with neutral solutes like glycerol, ammonia and silicic acid. Because NIP transporters are bidirectional, the movement of As(III) occurs in both ways between the plant cell and growth medium based on its concentration (Abbas et al., 2018). In rice, methylated arsenic species uptake is mediated through aquaporin influx Si transporter (Lsi1) and silicon efflux transporter (Lsi2), owing to the similarities between As (III) and Si.

\section{ARSENIC DETOXIFICATION MECHANISMS IN PLANTS}

One of the protection mechanisms from the generation of ROS due to arsenic presence in plants is the production of antioxidant enzymes like superoxide dismutase
(SOD), catalase (CAT), glutathione reductase (GR), and ascorbate peroxidase (APX) to balance the free radicals. The production/accumulation of certain osmolites like proline (Sayantan and Shardendu, 2017), glycinebetaine and mannitol are also seen in plants under oxidative stress as a means of protection and survival (Abbas et al., 2018). The major pathway of antioxidant defense to detoxify $\mathrm{H}_{2} \mathrm{O}_{2}$ is the Ascorbate-Glutathione pathway (AsA- GSH). Along with AsA and GSH, four enzymes viz. ascorbate peroxidase, monodehydroascorbate reductase, dehydroascorbate reductase, and glutathione reductase, play a vital role in detoxifying ROS in this pathway and plays a vital role in protecting the plant from various abiotic stresses as well (Hasanuzzaman et al., 2019).

Another mechanism includes the complexation of arsenic with ligands followed by the vacuolar compartmentation. Once arsenic enters the plant, $A s(V)$ would be reduced to As (III) form, with the help of enzyme arsenate reductase (AR) (Zhao et al., 2003). Arsenite is highly disruptive to the metabolomic process in the cytoplasm and hence detoxification occurs. This is observed in many plants like $H$. verticillata (with $>94 \%$ in As(III) form in shoots), Brassica juncea (with $96-100 \%$ in roots and shoots), tomato and rice (about 92-99\%) (Chen et al., 2015). Methyl arsonate [MA(V)] also reduces to MA(III) in rice shoots (Mishra et al., 2017). Inorganic arsenic and MA form complexes with metalbinding proteins like glutathione (GSH) or phytochelatins (PCs), which are then sequestrated into the vacuoles (Mishra et al., 2017; Pickering et al., 2000). GSH is a precursor of phytochelatins (PCs) (Thakur et al.,

Table 2. List of hyperaccumulator plants involved in phytoremediation of arsenic.

\begin{tabular}{ll}
\hline PLANTS & CHARACTERISTICS \\
\hline Pteris vittata $L$. & It is a fern with high translocation factor that can grow \\
& well on highly arsenic contaminated sites. It also has the \\
& potential to phytoremediate multiple toxic chemicals.
\end{tabular}

\section{SOURCE}

(Taylor et al., 2003)

(Chen et al., 2015)

(Raj and Singh, 2015)

(Visoottiviseth et al., 2002)

(Kochian, 2004)

(Xie et al., 2009)

Pteris cretica

It is a fern with greater arsenate influx in roots.

Pityrogramma
calomelanos

Adiantum capillus veneris

Brassica juncea
It is a fern that accumulates arsenic mostly in the fronds with ability to grow in highly contaminated areas. It can take up arsenic even from less contaminated areas. However, it is seen to be used as food in countries like Thailand.

It is a fern and are efficient root uptakers. They are fast growing plant and are also aesthetically pleasing.

It is a fern with a strong arsenic resistance.

It is a herbaceous plant. It is a highly resistant plant with ability to grow on soils of different nature.
(Raj and Singh, 2015)

(Poynton et al., 2004)

(Luongo and $\mathrm{Ma}, 2005$ )

(Luongo and $\mathrm{Ma}, 2005$ )

(Francesconi et al., 2002)

(Luongo and Ma, 2005)

(Koller et al., 2007)

(Raj and Singh, 2015)

(Singh et al., 2010)

(Pickering et al., 2000)

(Vocciante et al., 2019) 
2020). Phytochelatins are cysteine-rich, low molecular weight peptides. The exposure of arsenate induces the synthesis of PCs in several plant species (Mirza et al., 2014). This is the general strategy of detoxification employed by all plants irrespective of being hyperaccumulators or hypertolerants or non-hyperaccumulators (Chen et al., 2015). In hyperaccumulators, thiols have limited role and most a rsenic is stored as As (III) (Mishra et al., 2017). In leguminous plants, homo-PCs (hPCs) are synthesized along with PCs. Increased synthesis of PCs is observed in tolerant plants like H. lanatus (Tripathi et al., 2007).

\section{DISPOSAL OF PLANTS AFTER REMEDIATION}

The objective of phytoremediation will not be met if the plants used are not properly disposed of or handled after removing metals from the environment due to their storage in the biomass of the plants (Ghosh and Singh, 2005). The reutilization of end products of phytoremediation makes the process even more eco-friendly.

One option for the safe disposal of heavy metal-laden remediator plants would be composting. Composting will aid in the reduction of the volume of the biomass and also help in easy transport (Mohanty, 2016; Newete Byrne, 2016). The major drawback would be to transfer the hazardous substance from one place to another (Ghosh and Singh, 2005). Although techniques like stabilization/inertization by the application of lime can reduce the leachability of the metals (Vocciante et al., 2019), the plants have to dispose of not just anywhere but in specialized areas like tail mining. The disposal on the slopes of the tailing dam can act as mulches to put down the dust and would also give an opportunity for heavy metals to go back to where they belong after the process of decomposition and can reinstate the soil fertility for revegetation(Ghosh and Singh, 2005). Another method commonly used is incineration and the produced charcoal can be used as an energy source for cooking fires(Ghosh Singh, 2005). This method would obviously make sure that the biomass cannot be used for any other purposes like fertilizers or animal feed. But this could be a source of air pollution. Hence, its recommended that incineration is not performed in the open.

The next best alternative is pyrolysis - heating the biomass at temperatures typically between 350 and $650^{\circ}$ C in anaerobic conditions (Vocciante et al., 2019). The end products of pyrolysis are pyrolytic fluid oil and coke (Newete Byrne, 2016). The coke contains heavy metals which can be used in the smelter. The arsenate is also seen to reside in the pyrolytic residue when CCA treated wood is pyrolyzed at low temperatures, hence a better alternative (Helsen et al., 1997). Also, the gases like methanol or other liquids can be produced through the process of bio gasification, which can be utilized as a source of fuel (Mohanty, 2016). It is also seen that the biochar produced can be used to adsorb dye like methylene blue (Gong et al., 2018).

\section{Conclusion}

Arsenic, a potent carcinogen is seen to show its toxicity in both plants and animals. It is seen to impede the body's metabolism and hormone regulation. The increased anthropological activities leading to arsenic contamination in both soil and water systems is an issue in many countries and is to be properly addressed. Employing conventional methods like coagulation, lime softening, and adsorption may be effective to a certain level but might cause additional problems like large volumes of sludge generation, soil texture destruction, and being non-environmentally friendly. The greener alternative is phytoremediation. Proper identification and use of the arsenic hyperaccumulators and metaltolerant plants like Pteris vittata, Hydrilla verticilata, Micranthemum umbrosum will aid in the management of the arsenic problem naturally. In addition, genetically modified plants like transgenic tobacco, transgenic Arabidopsis thaliana can be utilised. However, the whole process would be to no purpose if the proper disposal methods are not followed. Apart from the scientific advancement, it is also crucial to increase awareness in the society regarding the measures that can be taken up, the type of plants that can be grown to control the arsenic pollution and the necessary precautions to be taken to prevent the pollution.

\section{ACKNOWLEDGEMENTS}

The authors are thankful to the Department of Life Sciences and Mr. Sreekumar Nair, Christ University, Bengaluru- 560029 (Karnataka), India.

\section{Conflict of interest}

The authors declare that they have no conflict of interest.

\section{REFERENCES}

1. Abbas, G., Murtaza, B., Bibi, I., Shahid, M., Niazi, N. K., Khan, M. I., Amjad, M., Hussain, M., \& Natasha (2018). Arsenic uptake, toxicity, detoxification, and speciation in plants: Physiological, biochemical, and molecular aspects. International Journal of Environmental Research and Public Health, 15(1), 59. https://doi.org/10.3390/ijerph150 10059

2. Abdulsalam, S., Bugaje, I. M., Adefila, S. S., \& Ibrahim, S. (2011). Comparison of biostimulation and bioaugmentation for remediation of soil contaminated with spent motor oil. International Journal of Environmental Science and Technology, 8(1), 187-194. https://doi.org/10.1007/ 
Meghana, K M and Sayantan, S / J. Appl. \& Nat. Sci. 13(3), 861 - 879 (2021)

BF03326208

3. Abedin, M. J., Feldmann, J., \& Meharg, A. A. (2002). Uptake kinetics of arsenic species in rice plants. Plant Physiology, 128(3), 1120-1128. https://doi.org/10.1104/ pp.010733

4. Ajayi, T. O., \& Ogunbayio, A. O. (2012). Achieving environmental sustainability in wastewater treatment by phytoremediation with water hyacinth (Eichhornia Crassipes). Journal of Sustainable Development, 5(7), 80-90. https://doi.org/10.5539/jsd.v5n7p80

5. Ali, H., Khan, E., \& Sajad, M. A. (2013). Phytoremediation of heavy metals-Concepts and applications. Chemosphere, 91(7), 869-881. https://doi.org/10.1016/ j.chemosphere.2013.01.075

6. Ali, I., Khan, T. A., \& Asim, M. (2011). Removal of arsenic from water by electrocoagulation and electrodialysis techniques. Separation and Purification Reviews, 40(1), 25-42. https://doi.org/10.1080/15422119.2011.542738

7. Alvarado, S., Guédez, M., Lué-merú, M. P., Nelson, G., Alvaro, A., Jesús, A. C., \& Gyula, Z. (2008). Bioresource technology arsenic removal from waters by bioremediation with the aquatic plants water hyacinth ( Eichhornia crassipes ) and Lesser Duckweed ( Lemna minor). Bioresource Technology, 99(17), 8436-8440. https:// doi.org/10.1016/j.biortech.2008.02.051

8. Anawar, H. M., Garcia-Sanchez, A., Tari Kul Alam, M., \& Majibur Rahman, M. (2008). Phytofiltration of water polluted with arsenic and heavy metals. International Journal of Environment and Pollution, 33(2-3), 292-312. https://doi.org/10.1504/IJEP.2008.019400

9. Atabaki, N., Shaharuddin, N. A., Ahmad, S. A., Nulit, R., \& Abiri, R. (2020). Assessment of water mimosa (Neptunia oleracea L.) morphological, physiological, and removal efficiency for phytoremediation of arsenicpolluted water. Plants, 9(11), 1500. https:// doi.org/10.3390/PLANTS9111500

10. Awasthi, S., Chauhan, R., Srivastava, S., \& Tripathi, R. D. (2017). The journey of arsenic from soil to Grain in Rice. Frontiers in Plant Science, 8, 1007. https:// doi.org/10.3389/fpls.2017.01007

11. Bencko, V., \& Foong, F. Y. L. (2017). The history of arsenical pesticides and health risks related to the use of Agent Blue. Annals of Agricultural and Environmental Medicine, 24(2), 312-316. https://doi.org/10.26444/aae $\mathrm{m} / 74715$

12. Bhargava, A., Carmona, F. F., Bhargava, M., \& Srivastava, S. (2012). Approaches for enhanced phytoextraction of heavy metals. Journal of Environmental Management, 105, 103-120. https://doi.org/10.1016/j.jenvman.2012.0 4.002

13. Bolan, N. S., Park, J. H., Robinson, B., Naidu, R., \& Huh, K. Y. (2011). Phytostabilization. A green approach to contaminant containment. Advances in Agronomy (Vol. 112). Academic Press. https://doi.org/10.1016/B978-0-12 -385538-1.00004-4

14. Brown, C. J., Eaton, R. A., \& Thorp, C. H. (2001). Effects of Chromated Copper Arsenate (CCA) wood preservative on early fouling community formation. Marine Pollution Bulletin, 42(11), 1103-1113. https://doi.org/10.1016/ S0025-326X(01)00095-9

15. Carbonell-Barrachina, A. A., Jugsujinda, A., Burlo, F., Delaune, R. D., \& Patrick, W. H. (2000). Arsenic chemis- try in municipal sewage sludge as affected by redox potential and $\mathrm{pH}$. Water Research, 34(1), 216-224. https://doi.org/10.1016/S0043-1354(99)00127-X

16. Chaudhary, B. K., \& Farrell, J. (2014). Preparation and characterization of homopolymer polyacrylonitrile-based fibrous sorbents for arsenic removal. Environmental Engineering Science, 31(11), 593-601. https://doi.org/10.10 89/EES.2014.0169

17. Chen, G., Liu, X., Brookes, P. C., \& Xu, J. (2015). Opportunities for Phytoremediation and Bioindication of Arsenic Contaminated Water Using a Submerged Aquatic Plant: Vallisneria natans ( lour .) Hara . International Journal of Phytoremediation, 17, 1-6. https://doi.or $\mathrm{g} / 10.1080 / 15226514.2014 .883496$

18. Chen, J., Garbinski, L. D., Rosen, B., Zhang, J., Xiang P., \& Ma, L. Q. (2020). Organoarsenical compounds: Occurrence, toxicology and biotransformation. Critical Reviews in Environmental Science and Technology, 50 (3), 217-243. https://doi.org/10.1080/10643389.201 9.1619375

19. Choong, T. S. Y., Chuah, T. G., Robiah, Y., Gregory Koay, F. L., \& Azni, I. (2007). Arsenic toxicity, health hazards and removal techniques from water: an overview. Desalination, 217(1-3), 139-166. https:// doi.org/10.1016/j.desal.2007.01.015

20. Chou, C. H. S. J., \& De Rosa, C. T. (2003). Case studies - Arsenic. International Journal of Hygiene and Environmental Health, 206(4-5), 381-386. https://doi.org/10.10 78/1438-4639-00234

21. Corroto, C., Iriel, A., Cirelli, A. F., \& Carrera, A. L. P. (2019). Constructed wetlands as an alternative for arsenic removal from reverse osmosis effluent. Science of the Total Environment, 691, 1242-1250. https:// doi.org/10.1016/j.scitotenv.2019.07.234

22. D'Ippoliti, D., Santelli, E., De Sario, M., Scortichini, M., Davoli, M., \& Michelozzi, P. (2015). Arsenic in drinking water and mortality for cancer and chronic diseases in Central Italy, 1990-2010. PLoS ONE, 10(9). https:// doi.org/10.1371/journal.pone.0138182

23. Das, N. K., \& Sengupta, S. R. (2008). Arsenicosis : Diagnosis and treatment. Indian Journal of Dermatology, Venereology and Leprology, 74(6), 571-581. 10.4103/0 378-6323.45098

24. David E. Salt, Michael Blaylock, Nanda P.B.A. Kumar Viatcheslav Dushenkov, I. C. \& I. R. (1995). Phytoremediation: A Novel Strategy for the Removal of Toxic Metals from the Environment Using Plants. Nature Biotechnology, 13, 468-474. https://doi.org/https://doi.org/10.10 38/nbt0595-468

25. de Souza, T. D., Borges, A. C., Braga, A. F., Veloso, R. W., \& Teixeira de Matos, A. (2019). Phytoremediation of arsenic-contaminated water by Lemna Valdiviana: An optimization study. Chemosphere, 234, 402-408. https:// doi.org/10.1016/J.CHEMOSPHERE.2019.06.004

26. Durthi, C. P., Rajulapati, S. B., Palliparambi, A. A., Kola, A. K., \& Sonawane, S. H. (2018). Studies on removal of arsenic using cellulose acetate-zinc oxide nanoparticle mixed matrix membrane. International Nano Letters, 8 (3), 201-211. https://doi.org/10.1007/S40089-018-0245-3

27. Dushenkov, V., Nanda Kumar, P. B. A., Motto, H., \& Raskin, I. (1995). Rhizofiltration: The Use of Plants To Remove Heavy Metals from Aqueous Streams. Environ- 
mental Science and Technology, 29(5), 1239-1245. https://doi.org/10.1021/es00005a015

28. Dwivedi, A., \& Bioremed Biodeg, J. (2015). Biological Wastes the Tool for Biosorption of Arsenic Bioremediation \& Biodegradation. Bioremediation \& Biodegradation, 7(1), 1. https://doi.org/10.4172/2155-6199.1000323

29. Edmonds, J. S., \& Francesconi, K. A. (1988). The origin of arsenobetaine in marine animals. Applied Organometallic Chemistry, 2(4), 297-302. https://doi.org/10.1002/aoc.59 0020404

30. Elshamy, M. M., Heikal, Y. M., \& Bonanomi, G. (2019). Phytoremediation efficiency of Portulaca oleracea $L$. naturally growing in some industrial sites, Dakahlia District, Egypt. Chemosphere, 225, 678-687. https://doi.org/10.10 16/j.chemosphere.2019.03.099

31. Favas, P. J. C., Pratas, J., \& Prasad, M. N. V. (2012). Accumulation of arsenic by aquatic plants in large-scale field conditions: Opportunities for phytoremediation and bioindication. Science of the Total Environment, 433, 390397. https://doi.org/10.1016/j.scitotenv.2012.06.091

32. Fayiga, A. O., Ma, L. Q., Cao, X., \& Rathinasabapathi, B. (2004). Effects of heavy metals on growth and arsenic accumulation in the arsenic hyperaccumulator Pteris vittata L. Environmental Pollution, 132(2), 289-296. https:// doi.org/10.1016/j.envpol.2004.04.020

33. Fisher, D. J., Yonkos, L. T., \& Staver, K. W. (2015). Environmental concerns of roxarsone in broiler poultry feed and litter in Maryland, USA. Environmental Science and Technology, 49(4), 1999-2012. https://doi.org/10.1021/ es504520w

34. Francesconi, K., Visoottiviseth, P., Sridokchan, W., \& Goessler, W. (2002). Arsenic species in an arsenic hyperaccumulating fern, Pityrogramma calomelanos: A potential phytoremediator of arsenic-contaminated soils. Science of the Total Environment, 284(1-3), 27-35. https://doi.org/1 0.1016/S0048-9697(01)00854-3

35. Garelick, H., Jones, H., Dybowska, A., \& Valsami-Jones, E. (2008). Arsenic pollution sources. Reviews of Environmental Contamination and Toxicology, 197, 17-60. https:// doi.org/10.1007/978-0-387-79284-2_2

36. Garg, N., \& Singla, P. (2011). Arsenic toxicity in crop plants: Physiological effects and tolerance mechanisms. Environmental Chemistry Letters, 9(3), 303-321. https:// doi.org/10.1007/s10311-011-0313-7

37. Ghosh, M., \& Singh, S. P. (2005). A Review on Phytoremediation of Heavy Metals and Utilization of It's by Products. Asian Journal on Energy and Environment, 6(04), 214-231.

38. Gong, X., Huang, D., Liu, Y., Zeng, G., Wang, R., Wei, J., Huang, C., Xu, P., Wan, J., \& Zhang, C. (2018). Pyrolysis and reutilization of plant residues after phytoremediation of heavy metals contaminated sediments: For heavy metals stabilization and dye adsorption. Bioresource Technology, 253, 64-71. https://doi.org/10.1016/j.biortech.201 8.01 .018

39. Greenleaf, J. E., Lin, J. C., \& Sengupta, A. K. (2006). Two novel applications of ion exchange fibers: Arsenic removal and chemical-free softening of hard water. Environmental Progress, 25(4), 300-311. https://doi.org/10.1002/ep.1 0163

40. Grill, E., Winnacker, E. L., \& Zenk, M. H. (1987). Phytochelatins, a class of heavy-metal-binding peptides from plants, are functionally analogous to metallothioneins. Proceedings of the National Academy of Sciences of the United States of America, 84(2), 439-443. https:// doi.org/10.1073/pnas.84.2.439

41. Guarino, F., Miranda, A., Castiglione, S., \& Cicatelli, A. (2020). Arsenic phytovolatilization and epigenetic modifications in Arundo donax L. assisted by a PGPR consortium. Chemosphere, 251, 126310. https://doi.org/10.1016/ J.CHEMOSPHERE.2020.126310

42. Ha, N. T. H., Sakakibara, M., \& Sano, S. (2011). Accumulation of Indium and other heavy metals by Eleocharis acicularis: An option for phytoremediation and phytomining. Bioresource Technology, 102(3), 2228-2234. https://doi.org/10.1016/j.biortech.2010.10.014

43. Hasanuzzaman, M., Borhannuddin Bhuyan, M. H. M., Anee, T. I., Parvin, K., Nahar, K., Al Mahmud, J., \& Fujita, M. (2019). Regulation of ascorbate-glutathione pathway in mitigating oxidative damage in plants under abiotic stress. Antioxidants, 8(9). https://doi.org/10.3390/antiox8090384

44. Hashmi, F., \& Pearce, J. M. (2011). Viability of SmallScale Arsenic-Contaminated-Water Purifi cation Technologies for Sustainable Development in Pakistan. Sustainable Development, 19(4), 223-234. https://doi.org/https:// doi.org/10.1002/sd.414

45. Heaton, A. C. P., Rugh, C. L., Wang, N. J., \& Meagher, R. B. (1998). Phytoremediation of mercury- and methylmercury-polluted soils using genetically engineered plants. Soil and Sediment Contamination, 7(4), 497-509. https:// doi.org/10.1080/10588339891334384

46. Helsen, L., Van den Bulck, E., Van den Broeck, K., \& Vandecasteele, C. (1997). Low-temperature pyrolysis of CCA-treated wood waste: Chemical determination and statistical analysis of metal input and output; mass balances. Waste Management, 17(1), 79-86. https:// doi.org/10.1016/S0956-053X(97)00040-8

47. Hering, J. G., Chen, P. Y., Wilkie, J. A., Elimelech, M., \& Liang, S. (1996). Arsenic removal by ferric chloride. Journal / American Water Works Association, 88(4), 155-167. https://doi.org/10.1002/j.1551-8833.1996.tb06541.x

48. Hingston, J. A., Collins, C. D., Murphy, R. J., \& Lester, J. N. (2001). Leaching of chromated copper arsenate wood preservatives: A review. Environmental Pollution, 111(1), 53-66. https://doi.org/10.1016/S0269-7491(00)00030-0

49. Howard, S. G. (2018). Developmental exposure to endocrine disrupting chemicals and type 1 diabetes mellitus. Frontiers in Endocrinology, 9(9), 513. https:// doi.org/10.3389/fendo.2018.00513

50. Irshad, S., Xie, Z., Mehmood, S., Nawaz, A., Ditta, A., \& Mahmood, Q. (2021). Insights into conventional and recent technologies for arsenic bioremediation: A systematic review. Environmental Science and Pollution Research, 28(15), 18870-18892. https://doi.org/10.1007/s11356-021 $-12487-8$

51. Islam, M. S., Saito, T., \& Kurasaki, M. (2015). Phytofiltration of arsenic and cadmium by using an aquatic plant, Micranthemum umbrosum: Phytotoxicity, uptake kinetics, and mechanism. Ecotoxicology and Environmental Safety, 112, 193-200. https://doi.org/10.1016/j.ecoenv.2014.11.0 06

52. Islam, M. S., Sikder, M. T., \& Kurasaki, M. (2017). Potential of Micranthemum umbrosum for phytofiltration of organic arsenic species from oxic water environment. Inter- 
national Journal of Environmental Science and Technology, 14(2), 285-290. https://doi.org/10.1007/s13762-016$1142-9$

53. Jasrotia, S., Kansal, A., \& Kishore, V. V. N. (2014). Arsenic phyco-remediation by Cladophora algae and measurement of arsenic speciation and location of active absorption site using electron microscopy. Microchemical Journal, 114, 197-202. https://doi.org/10.1016/j.microc.2014.0 1.005

54. Jones, F. T. (2007). A broad view of arsenic. Poultry Science, 86(1), 2-14. https://doi.org/10.1093/ps/86.1.2

55. Joseph, J., Reddy, J., \& Sayantan, D. (2018). Effect of nickel uptake on selected growth parameters of Amaranthus viridis L. Journal of Applied and Natural Science, 10 (3), 1011-1017. https://doi.org/10.31018/jans.v10i3.1838

56. Karimi, N., Seyed Majid Ghaderian, A. R., Feldmann, J., \& Meharg, A. A. (2003). An arsenic-accumulating, hypertolerant brassica, Isatis capadocica. The Journal of Physiology, 547(3), 971-976. https://doi.org/10.1111/j..2003.t01 $-2-00971 . x$

57. Kartinen, E. O., \& Martin, C. J. (1995). An overview of arsenic removal processes. Desalination, 103(1-2), 7988. https://doi.org/10.1016/0011-9164(95)00089-5

58. Katsoyiannis, I. A., \& Zouboulis, A. I. (2006). Comparative evaluation of conventional and alternative methods for the removal of arsenic from contaminated groundwaters. Reviews on Environmental Health, 21(1), 25-41. https:// doi.org/10.1515/REVEH.2006.21.1.25

59. Khatamian, M., Khodakarampoor, N., \& Saket-Oskoui, M. (2017). Efficient removal of arsenic using graphene-zeolite based composites. Journal of Colloid and Interface Science, 498, 433-441. https://doi.org/10.1016/J.JC IS.2017.03.052

60. King, D. J., Doronila, A. I., Feenstra, C., Baker, A. J. M., \& Woodrow, I. E. (2008). Phytostabilisation of arsenical gold mine tailings using four Eucalyptus species: Growth, arsenic uptake and availability after five years. Science of the Total Environment, 406(1-2), 35-42. https:// doi.org/10.1016/j.scitotenv.2008.07.054

61. Klaber, N. S., \& Barker, A. V. (2014). Accumulation of Phosphorus and Arsenic in Two Perennial Grasses for Soil Remediation. Communications in Soil Science and Plant Analysis, 45(6), 810-818. https:/l doi.org/10.1080/00103624.2013.857681

62. Kochian, L. V. (2004). Phytofiltration of Arsenic from Drinking Water Using Arsenic-Hyperaccumulating Ferns. Environmental Science and Technology, 38(12), 34123417. https://doi.org/https://doi.org/10.1021/es0351645

63. Koller, C. E., Patrick, J. W., Rose, R. J., Offler, C. E., \& MacFarlane, G. R. (2007). Pteris umbrosa R. Br. as an arsenic hyperaccumulator: accumulation, partitioning and comparison with the established As hyperaccumulator Pteris vittata. Chemosphere, 66(7), 1256-1263. https:// doi.org/10.1016/j.chemosphere.2006.07.029

64. Kozul, C. D., Ely, K. H., Enelow, R. I., \& Hamilton, J. W. (2009). Low-dose arsenic compromises the immune response to influenza A infection in vivo. Environmental Health Perspectives, 117(9), 1441-1447. https:// doi.org/10.1289/ehp.0900911

65. Krämer, U. (2005). Phytoremediation: Novel approaches to cleaning up polluted soils. Current Opinion in Biotechnology, 16(2), 133-141. https://doi.org/10.1016/ j.copbio.2005.02.006

66. Lalita N Abhyankar, Miranda R Jones, Eliseo Guallar, A. N.-A. (2012). Review Arsenic Exposure and Hypertension: A Systematic Review. Environmental Health Perspectives, 120(4), 494-500. https://doi.org/10.1289/ ehp. 1103988

67. Lee, C. G., Alvarez, P. J. J., Nam, A., Park, S. J., Do, T., Choi, U. S., \& Lee, S. H. (2017). Arsenic(V) removal using an amine-doped acrylic ion exchange fiber: Kinetic, equilibrium, and regeneration studies. Journal of Hazardous Materials, 325, 223-229. https://doi.org/10.1016/ J.JHAZMAT.2016.12.003

68. Lee, C. P., \& Wen, L. S. (2019). Physical and chemical characterization of dissolved arsenic in the South China Sea. Marine Chemistry, 209(January), 128-138. https:// doi.org/10.1016/j.marchem.2019.02.001

69. Li, B., Gu, B., Yang, Z., \& Zhang, T. (2018a). The role of submerged macrophytes in phytoremediation of arsenic from contaminated water: A case study on Vallisneria natans (Lour.) Hara. Ecotoxicology and Environmental Safety, 165(August), 224-231. https://doi.org/10.1016/ j.ecoenv.2018.09.023

70. Li, G., Khan, S., Ibrahim, M., Sun, T. R., Tang, J. F., Cotner, J. B., \& Xu, Y. Y. (2018b). Biochars induced modification of dissolved organic matter (DOM) in soil and its impact on mobility and bioaccumulation of arsenic and cadmium. Journal of Hazardous Materials, 348(October 2017), 100-108. https://doi.org/10.1016/j.jhazmat.2018.0 1.031

71. Lizama A., K., Fletcher, T. D., \& Sun, G. (2011). Removal processes for arsenic in constructed wetlands. Chemosphere, 84(8), 1032-1043. https://doi.org/10.1016/ j.chemosphere.2011.04.022

72. Li, Z., Wang, L., Meng, J., Liu, X., Xu, J., Wang, F., \& Brookes, P. (2018c). Zeolite-supported nanoscale zerovalent iron: New findings on simultaneous adsorption of $\mathrm{Cd}(\mathrm{II}), \mathrm{Pb}(\mathrm{II})$, and $\mathrm{As}(\mathrm{III})$ in aqueous solution and soil. Journal of Hazardous Materials, 344, 1-11. https:// doi.org/10.1016/J.JHAZMAT.2017.09.036

73. Litynska, M., Ihor, A., Tolstopalova, N., Astrelin, I., \& Tolstopalova, N. (2017). Ways of Arsenic Compounds Getting into Natural Waters . Modern Environmental Science and Engineering, 3(1), 50-60. https://doi.org/10.15341/ mese(2333-2581)/01.03.2017/007

74. Litynska, M. \& Babakov, O. (2019). Ecological assessment of different arsenic removal methods in water treatment. Seventh International Scientific and Practical Conference, 301-305. https://ela.kpi.ua/handle/1234567 $89 / 27908$

75. Luongo, T., \& Ma, L. Q. (2005). Characteristics of arsenic accumulation by Pteris and non- Pteris ferns. Plant and Soil, 277, 117-126. https://doi.org/10.1007/s11104-0056335-9

76. Magalhães, M. C. F. (2002). Arsenic . An environmental problem limited by solubility. Pure and Applied Chemistry, 74(10), 1843-1850. https://doi.org/https://doi.org/10.1351/ pac200274101843

77. Mandal, P., Debbarma, S. R., Saha, A., \& Ruj, B. (2016). Disposal Problem of Arsenic Sludge Generated During Arsenic Removal from Drinking Water. Procedia Environmental Sciences, 35, 943-949. https://doi.org/10.1016/ j.proenv.2016.07.084 
78. Mandal, B. K., \& Suzuki, K. T. (2002). Arsenic round the world: A review. Talanta, 58(1), 201-235. https:// doi.org/10.1016/S0039-9140(02)00268-0

79. Mandal, P. (2017). An insight of environmental contamination of arsenic on animal health. Emerging Contaminants, 3(1), 17-22. https://doi.org/10.1016/j.emcon.2017.01.004

80. Martin, E., González-Horta, C., Rager, J., Bailey, K. A., Sánchez-Ramírez, B., Ballinas-Casarrubias, L., Ishida, M. C., Gutiérrez-Torres, D. S., Cerón, R. H., Morales, D. V., Terrazas, F. A. B., Jesse Saunders, R., Drobná, Z., Mendez, M. A., Buse, J. B., Loomisk, D., Jiakj, W., GarcíaVargaskk, G. G., Del Razo, L. M., ... Fry, R. (2015). Metabolomic characteristics of arsenic-associated diabetes in a prospective cohort in Chihuahua, Mexico. Toxicological Sciences, 144(2), 338-346. https://doi.org/10.1093/ toxsci/kfu318

81. Mary Kensa, V. (2011). Bioremediation - An overview Journal of Industrial Pollution Control, 27(2), 161-168.

82. McGregor, D., Boobis, A., Binaglia, M., Botham, P., Hoffstadt, L., Hubbard, S., Petry, T., Riley, A., Schwartz, D., \& Hennes, C. (2010). Guidance for the classification of carcinogens under the globally harmonised system of classification and labelling of chemicals (GHS). Critical Reviews in Toxicology, 40(3), 245-285. https://doi.org/10.3109/10 408440903384717

83. Meakin, C. J., Martin, E. M., Szilagyi, J. T., NylanderFrench, L. A., \& Fry, R. C. (2019). Inorganic Arsenic as an Endocrine Disruptor: Modulation of the Glucocorticoid Receptor Pathway in Placental Cells via CpG Methylation. Chemical Research in Toxicology, 32(3), 493-499. https:// doi.org/10.1021/acs.chemrestox.8b00352

84. Melkonian, S., Argos, M., Pierce, B. L., Chen, Y., Islam, T., Ahmed, A., Syed, E. H., Parvez, F., Graziano, J., Rathouz, P. J., \& Ahsan, H. (2011). A prospective study of the synergistic effects of arsenic exposure and smoking, sun exposure, fertilizer use, and pesticide use on risk of premalignant skin lesions in bangladeshi men. American Journal of Epidemiology, 173(2), 183-191. https://doi.or g /10.1093/aje/kwq357

85. Mirza, N., Mahmood, Q., Maroof Shah, M., Pervez, A., \& Sultan, S. (2014). Plants as useful vectors to reduce environmental toxic arsenic content. The Scientific World Journal, 2014, 11. https://doi.org/10.1155/2014/921581

86. Mirza, N., Pervez, A., Mahmood, Q., Shah, M. M., \& Shafqat, M. N. (2011). Ecological restoration of arsenic contaminated soil by Arundo donax L. Ecological Engineering, 37(12), 1949-1956. https://doi.org/10.1016/ j.ecoleng.2011.07.006

87. Misbahuddin, M., \& Fariduddin, A. (2010). Water Hyacinth Removes Arsenic from Arsenic- Contaminated Drinking Water Water Hyacinth Removes Arsenic from ArsenicContaminated Drinking Water. Archives of Environmental Health: An International Journal, 57(May 2012), 3-6. https://doi.org/https://doi.org/10.1080/0003989020960208 2

88. Mishra, S., Mattusch, J., \& Wennrich, R. (2017). Accumulation and transformation of inorganic and organic arsenic in rice and role of thiol-complexation to restrict their translocation to shoot. Scientific Reports, 7(40522). https:// doi.org/10.1038/srep40522

89. Mizuta, N., Mizuta, M., Ito, F., Ito, T., Uchida, H., Watanabe, Y., Akama, H., Murakami, T., Hayashi, F., Nakamura, K., Yamaguchi, T., Mizuta, W., Oishi, S., \&
Matsumura, H. (1956). An outbreak of acute arsenic poisoning caused by arsenic contaminated soy-sauce (shoyu): a clinical report of 220 cases. Nihon Naika Gakkai Zasshi, 45(8), 867-880. https://doi.org/10.2169/ naika. 45.867

90. Mohanty, M. (2016). Post-harvest management of phytoremediation technology. Journal of Environmental \& Analytical Toxicology, 6(5). https://doi.org/10.4172/21610525.1000398

91. Mykolenko, S., Liedienov, V., Kharytonov, M., Makieieva, N., Kuliush, T., Queralt, I., Marguí, E., Hidalgo, M., Pardini, G., Gispert, M., Wali, A., Colinet, G., Ksibi, M., Muntau, H., Quevauviller, P., Griepink, B., Dukši, I., Vincek, D., Horváth, M., Jiménez, M. N. (2013). Phytoremediation of metal enriched mine waste: a review. Global Journal of Environmental Research, 70(4), 135-151. http:// dx.doi.org/10.1016/j.gexplo.2016.09.013\%0Ahttps:// doi.org/10.1016/j.envpol.2018.02.053

92. Mukhopadhyay, M., Lakhotia, S. R., Ghosh, A. K., \& Bindal, R. C. (2018). Removal of arsenic from aqueous media using zeolite/chitosan nanocomposite membrane. Separation science and technology, 54(2), 282-288. https://doi.org/10.1080/01496395.2018.1459704

93. Nahar, N., Rahman, A., Nawani, N. N., Ghosh, S., \& Mandal, A. (2017). Phytoremediation of arsenic from the contaminated soil using transgenic tobacco plants expressing ACR2 gene of Arabidopsis thaliana. Journal of Plant Physiology, 218, 121-126. https://doi.org/10.1016/ j.jplph.2017.08.001

94. Naidu, R., Smith, E., Owens, G., \& Bhattacharya, P. (2006). Managing Arsenic in the Environment: From Soil to Human Health (Google eBook) (Issue May 2014). CSIRO publishing. http://books.google.com/books? $\mathrm{hl}=e n \& \mid \mathrm{r}=\& \mathrm{id}=\mathrm{iz} V \mathrm{jtg} \mathrm{W} O$ \&kC\&pgis=1

95. Nedjimi, B. (2021). Phytoremediation: a sustainable environmental technology for heavy metals decontamination. SN Applied Sciences, 3(3). https://doi.org/10.1007/s42452 $-021-04301-4$

96. Newete, S. W., \& Byrne, M. J. (2016). The capacity of aquatic macrophytes for phytoremediation and their disposal with specific reference to water hyacinth. Environmental Science and Pollution Research, 23(11), 1063010643. https://doi.org/10.1007/s11356-016-6329-6

97. Niazi, N. K., Bibi, I., Fatimah, A., Shahid, M., Javed, T., Wang, H., Ok, Y. S., Bashir, S., Murtaza, B., Ahmad, Z., Shakoor, M. B., Geoscience, S. C., Road, A. I., Biochar, K., \& Science, E. (2017). Phosphate-assisted phytoremediation of arsenic by Brassica napus and Brassica juncea: Morphological and physiological response. International Journal of Phytoremediation, 19(7), 670-678. https:// doi.org/10.1080/15226514.2016.1278427

98. Nidheesh, P. V., \& Singh, T. S. A. (2017). Arsenic removal by electrocoagulation process: Recent trends and removal mechanism. Chemosphere, 181, 418-432. https:// doi.org/10.1016/j.chemosphere.2017.04.082

99. Ortega, A., Oliva, I., Contreras, K. E., González, I., CruzDíaz, M. R., \& Rivero, E. P. (2017). Arsenic removal from water by hybrid electro-regenerated anion exchange resin/ electrodialysis process. Separation and Purification Technology, 184, 319-326. https://doi.org/10.1016/j.seppur.20 17.04.050

100.Palma-Lara, I., Martínez-Castillo, M., Quintana-Pérez, J. 
C., Arellano-Mendoza, M. G., Tamay-Cach, F., Valenzuela-Limón, O. L., García-Montalvo, E. A., \& HernándezZavala, A. (2020). Arsenic exposure: A public health problem leading to several cancers. Regulatory Toxicology and Pharmacology, 110, 104539. https://doi.org/10.1016/ j.yrtph.2019.104539

101.Pandey, D., Zoomi, I., Akhtar, O., Srivastava, P., \& Kehri, H. K. (2018). Approaches for Remediation of Arsenic Contamination from Soil and Water: A Review . International Journal of Life Sciences Research, 6(3), 146-162. https:// www.researchgate.net/publication/327402965

102.Peryea, F. J., \& Creger, T. L. (1994). Vertical distribution of lead and arsenic in soils contaminated with lead arsenate pesticide residues. Water, Air, \& Soil Pollution, 78(34), 297-306. https://doi.org/10.1007/BF00483038

103.Pham, M. T., Nishihama, S., \& Yoshizuka, K. (2021). Effect of Operational Conditions on Arsenic Removal from Aqueous Solution Using Electrodialysis. Solvent Extraction and lon Exchange. https:// doi.org/10.1080/07366299.2021.1876987

104.Phillips, J., \& French, M. (1998). The pure beer campaign and arsenic poisoning, 1896-1903. Rural History, 9(2), 195-209. https://doi.org/10.1017/s0956793300001576

105.Pickering, I. J., Prince, R. C., George, M. J., Smith, R. D., George, G. N., \& Salt, D. E. (2000). Reduction and Coordination of Arsenic in Indian Mustard 1. Plant Physiology, 122(4), 1171-1178. https://doi.org/10.1104/pp.122.4.1171

106.Poynton, C. Y., Huang, J. W., Blaylock, M. J., Kochian, L. V., \& Elless, M. P. (2004). Mechanisms of arsenic hyperaccumulation in Pteris species: Root As influx and translocation. Planta, 219(6), 1080-1088. https://doi.org/10.1007/ s00425-004-1304-8

107.Rahman, M. A., \& Hasegawa, H. (2011). Aquatic arsenic: Phytoremediation using floating macrophytes. Chemosphere, 83(5), 633-646. https://doi.org/10.1016/ j.chemosphere.2011.02.045

108.Rahman, M. A., Hasegawa, H., Ueda, K., Maki, T., Okumura, C., \& Rahman, M. M. (2007). Arsenic accumulation in duckweed (Spirodela polyrhiza L.): A good option for phytoremediation. Chemosphere, 69(3), 493-499. https:// doi.org/10.1016/j.chemosphere.2007.04.019

109.Rahman, M. S., Clark, M. W., Yee, L. H., \& Burton, E. D. (2019). Arsenic(V) sorption kinetics in long-term arsenic pesticide contaminated soils. Applied Geochemistry, 111 (June), $\quad 104444 . \quad$ https://doi.org/10.1016/ j.apgeochem.2019.104444

110.Raj, A., \& Singh, N. (2015). Phytoremediation of Arsenic Contaminated Soil by Arsenic Accumulators: A Three Year Study. Bulletin of Environmental Contamination and Toxicology, 94(3). https://doi.org/10.1007/s00128-0151486-8

111.Raj, D. (2019). Bioaccumulation of mercury, arsenic, cadmium, and lead in plants grown on coal mine soil. Human and Ecological Risk Assessment, 25(3), 659-671. https:// doi.org/10.1080/10807039.2018.1447360

112.Ranjan, A., Singh, S., Kumar, V., \& Majhi, M. (2020). Remediation Measures for Arsenic Pollution of Soil. Biotica Research Today, 2(7), 680-683. https:// bioticainternational.com/ojs/index.php/biorestoday/article/ view/331

113.Robinson, B., Duwig, C., Bolan, N., Kannathasan, M., \&
Saravanan, A. (2003). Uptake of arsenic by New Zealand watercress (Lepidium sativum). Science of the Total Environment, 301(1-3), 67-73. https://doi.org/10.1016/S00489697(02)00294-2

114.Robinson, B., Kim, N., Marchetti, M., Moni, C., Schroeter, L., Dijssel, C. Van Den, Milne, G., \& Clothier, B. (2006). Arsenic hyperaccumulation by aquatic macrophytes in the Taupo Volcanic Zone, New Zealand. Environmental and Experimental Botany, 58(1-3), 206-215. https:// doi.org/10.1016/j.envexpbot.2005.08.004

115.Reddy, S. (2019). Arsenic contamination in Ground Water in India - Vikaspedia. Retrieved July 15, 2021, https:// vikaspedia.in/energy/environment/know-yourenvironment/water/arsenic-contamination-in-ground-water -in-india

116.Sadeghi, M. H., Tofighy, M. A., \& Mohammadi, T. (2020). One-dimensional graphene for efficient aqueous heavy metal adsorption: Rapid removal of arsenic and mercury ions by graphene oxide nanoribbons (GONRs). Chemosphere, 253, 126647. https://doi.org/10.1016/ J.CHEMOSPHERE.2020.126647

117.Sakakibara, M., Watanabe, A., Sano, S., Inoue, M., \& Kaise, T. (2007). Phytoextraction and phytovolatilization of arsenic from as-contaminated soils by Pteris vittata.Proceedings of the Annual International Conference on Soils, Sediments, Water and Energy, 12(January), 258 -263 .

118.Sanchez-Hernandez, J. C., Ro, K. S., \& Díaz, F. J. (2019). Biochar and earthworms working in tandem: Research opportunities for soil bioremediation. Science of the Total Environment, 688, 574-583. https:// doi.org/10.1016/j.scitotenv.2019.06.212

119.Sandhi, A., Landberg, T., \& Greger, M. (2018). Phytofiltration of arsenic by aquatic moss (Warnstorfia fluitans). Environmental Pollution, 237, 1098-1105. https:// doi.org/10.1016/j.envpol.2017.11.038

120.Sasmaz, A., \& Obek, E. (2009). The accumulation of arsenic , uranium , and boron in Lemna gibba $\mathrm{L}$. exposed to secondary effluents. Ecological Engineering, 35(10), 1564-1567. https://doi.org/10.1016/j.ecoleng.2009.06.007

121.Sayantan, D., \& Shardendu. (2017). Phosphate Amendments Moderate the Arsenate Accumulation and Its Subsequent Oxidative and Physiological Toxicities in Amaranthus viridis L. Proceedings of the National Academy of Sciences India Section B - Biological Sciences, 87(4), 1343-1353. https://doi.org/10.1007/s40011-016-0711-5

122. Shaji, E., Santosh, M., Sarath, K. V., Prakash, P., Deepchand, V., \& Divya, B. V. (2021). Arsenic contamination of groundwater: A global synopsis with focus on the Indian Peninsula. Geoscience Frontiers, 12(3), 101079. https:// doi.org/10.1016/j.gsf.2020.08.015

123.Sharma, I. (2012). Arsenic induced oxidative stress in plants. Biologia, 67(3), 447-453. https://doi.org/10.2478/ s11756-012-0024-y

124.Shrivastava, A., Ghosh, D., Dash, A., \& Bose, S. (2015). Arsenic Contamination in Soil and Sediment in India: Sources, Effects, and Remediation. Current Pollution Reports, 1(1), 35-46. https://doi.org/10.1007/s40726-0150004-2

125.Signes-Pastor, A., Burló, F., Mitra, K., \& CarbonellBarrachina, A. A. (2007). Arsenic biogeochemistry as 
affected by phosphorus fertilizer addition, redox potential and $\mathrm{pH}$ in a west Bengal (India) soil. Geoderma, 137(3-4), 504-510. https://doi.org/10.1016/j.geoderma.2006.10.012

126.Silva Gonzaga, M. I., Gonzaga Santos, J. A., \& Ma, L. Q. (2006). Arsenic phytoextraction and hyperaccumulation by fern species. Scientia Agricola, 63(1), 90-101. https:// doi.org/10.1590/s0103-90162006000100015

127.Singh, N., Raj, A., Khare, P. B., Tripathi, R. D., \& Jamil, S. (2010). Arsenic accumulation pattern in 12 Indian ferns and assessing the potential of Adiantum capillus-veneris , in comparison to Pteris vittata , as arsenic hyperaccumulator. Bioresource Technology, 101(23), 8960-8968. https://doi.org/10.1016/j.biortech.2010.06.116

128.Slavkovich, V., Argos, M., Hasan, R., Ahmed, A., \& Islam, T. (2013). Arsenic Exposure and Impaired Lung Function. Findings from a Large Population-based Prospective Cohort Study. American Journal of Respiratory and Critical Care Medicine, 188(7), 813-819. https://doi.org/10.1164/ rccm.201212-2282OC

129.Smedley, P. L., \& Kinniburgh, D. G. (2002). A review of the source, behaviour and distribution of arsenic in natural waters. Applied Geochemistry, 17(5), 517-568. https:// doi.org/https://doi.org/10.1016/S0883-2927(02)00018-5

130.Sodhi, K. K., Kumar, M., Agrawal, P. K., \& Singh, D. K. (2019). Perspectives on arsenic toxicity, carcinogenicity and its systemic remediation strategies. Environmental Technology and Innovation, 16, 100462. https://doi.org/1 0.1016/j.eti.2019.100462

131.Song, Z., Chen, X., Gong, X., Gao, X., Dai, Q., Nguyen, T. T., \& Guo, M. (2020). Luminescent carbon quantum dots/nanofibrillated cellulose composite aerogel for monitoring adsorption of heavy metal ions in water. Optical Materials, 100, 109642. https://doi.org/10.1016/J.OPTMA T.2019.109642

132.Song, W. Y., Park, J., Mendoza-Cózatl, D. G., SuterGrotemeyer, M., Shima, D., Hörtensteiner, S., Geisler, M., Weder, B., Rea, P. A., Rentsch, D., Schroeder, J. I., Lee, Y., \& Martinoia, E. (2010). Arsenic tolerance in Arabidopsis is mediated by two ABCC-type phytochelatin transporters. Proceedings of the National Academy of Sciences of the United States of America, 107(49), 21187-21192. https://doi.org/10.1073/pnas.1013964107

133.Srivastava, S., \& Dwivedi, A. (2015). Biological Wastes the Tool for Biosorption of Arsenic. Bioremediation \& Biodegradation, 7(1), 1. https://doi.org/10.4172/2155-6199.10 00323

134.Sultana, R., \& Kobayashi, K. (2011). Potential of barnyard grass to remediate arsenic-contaminated soil. Weed Biology and Management, 11(1), 12-17. https://doi.org/10.1 111/j.144 5-6664.2011.00400.x

135.Taylor, P., Mendoza, R. M. O., Kan, C., Chuang, S., \& Pingul-ong, S. M. B. (2014). Feasibility studies on arsenic removal from aqueous solutions. Journal of Environmental Science and Health , Part A: Toxic / Hazardous Substances and Environmental engineering, 49(5), 545-554 . https://doi.org/10.1080/10934529.2014.859035

136.Taylor, P., Salido, A. L., Hasty, K. L., Lim, J., Butcher, D. J., Salido, A. L., Hasty, K. L., Lim, J., \& Butcher, D. J. (2003). Phytoremediation of Arsenic and Lead in Contaminated Soil Using Chinese Brake Ferns ( Pteris vittata) and Indian Mustard ( Brassica juncea ). International Journal of Phytoremediation, 5, 89-103. https:// doi.org/10.1080/713610173

137.Thakur, S., Choudhary, S., Majeed, A., Singh, A., \& Bhardwaj, P. (2020). Insights into the Molecular Mechanism of Arsenic Phytoremediation. Journal of Plant Growth Regulation, 39(2), 532-543. https:// doi.org/10.1007/s00344-019-10019-w

138. Tripathi, R. D., Srivastava, S., Mishra, S., Singh, N., Tuli, R., Gupta, D. K., \& Maathuis, F. J. M. (2007). Arsenic hazards: strategies for tolerance and remediation by plants. Trends in Biotechnology, 25(4), 158-165. https:// doi.org/10.1016/j.tibtech.2007.02.003

139.Tripti, K., Narain Singh, D., \& Sayantan, D. (2017). Evaluation of arsenic removal potential of arsenic resistant bacteria with the role of physiological and genomic factors.Indian Journal of Experimental Biology 55, 251- 261.

140.Tripti, K., Sayantan, D., Shardendu, S., Singh, D. N., \& Tripathi, A. K. (2014). Potential for the uptake and removal of arsenic [As (V) and As (III)] and the reduction of As (V) to As (III) by Bacillus licheniformis(DAS1) under different stresses. Korean Journal of Microbiology and Biotechnology, 42(3), 238-248. https://doi.org/10.4014/kjmb.1401.0 1004

141.Upadhyay, M. K., Shukla, A., Yadav, P., \& Srivastava, S. (2019). A review of arsenic in crops, vegetables, animals and food products. Food Chemistry, 276, 608-618. https:// doi.org/10.1016/j.foodchem.2018.10.069

142. Vatamaniuk, O. K., Mari, S., Lu, Y. P., \& Rea, P. A. (2000). Mechanism of heavy metal ion activation of phytochelatin (PC) synthase. Blocked thiols are sufficient for PC synthase-catalyzed transpeptidation of glutathione and related thiol peptides. Journal of Biological Chemistry, 275 (40), 31451-31459. https://doi.org/10.1074/jbc.M002 997 200

143. Visoottiviseth, P., Francesconi, K., \& Sridokchan, W. (2002). The potential of Thai indigenous plant species for the phytoremediation of arsenic contaminated land. Environmental Pollution, 118(3), 453-461. https://doi.org/ https://doi.org/10.1016/S0269-7491(01)00293-7

144.Vithanage, M., Dabrowska, B. B., Mukherjee, A. B., Sandhi, A., \& Bhattacharya, P. (2012). Arsenic uptake by plants and possible phytoremediation applications: A brief overview. Environmental Chemistry Letters, 10(3), 217224. https://doi.org/10.1007/s10311-011-0349-8

145. Vocciante, M., Caretta, A., Bua, L., Bagatin, R., Franchi, E., Petruzzelli, G., \& Ferro, S. (2019). Enhancements in phytoremediation technology: Environmental assessment including different options of biomass disposal and comparison with a consolidated approach. Journal of Environmental Management, 237(November 2018), 560-568. https://doi.org/10.1016/j.jenvman.2019.02.104

146.Xie, Q. E., Yan, X. L., Liao, X. Y., \& Li, X. (2009). The arsenic hyperaccumulator fern Pteris vittata L. Environmental Science and Technology, 43(22), 8488-8495. https://doi.org/10.1021/es9014647

147.Xie, Z. M., \& Huang, C. Y. (1998). Control of arsenic toxicity in rice plants grown on an arsenic-polluted paddy soil. Communications in Soil Science and Plant Analysis, 29 (15-16), 2471-2477. https://doi.org/10.1080/0010 362980 9370125

148.Xue, P. ying, \& Yan, C. zhou. (2011). Arsenic accumulation and translocation in the submerged macrophyte $\mathrm{Hy}$ drilla verticillata (L.f.) Royle. Chemosphere, 85(7), 1176- 
1181. https://doi.org/10.1016/j.chemosphere.2011.09.051

149. Yamaguchi, N., Nakamura, T., Dong, D., Takahashi, Y., Amachi, S., \& Makino, T. (2011). Arsenic release from flooded paddy soils is influenced by speciation, Eh, $\mathrm{pH}$, and iron dissolution. Chemosphere, 83(7), 925-932. https://doi.org/10.1016/j.chemosphere.2011.02.044

150.Zhang, X., Hu, Y., Liu, Y., \& Chen, B. (2011). Arsenic uptake, accumulation and phytofiltration by duckweed
(Spirodela polyrhiza L.). Journal of Environmental Sciences, 23(4), 601-606. https://doi.org/10.1016/S1001-0742 (10)60454-8

151.Zhao, F. J., Wang, J. R., Barker, J. H. A., Schat, H., Bleeker, P. M., \& McGrath, S. P. (2003). The role of phytochelatins in arsenic tolerance in the hyperaccumulator Pteris vittata. New Phytologist, 159(2), 403-410. https:// doi.org/10.1046/j.1469-8137.2003.00784.x 